NBER WORKING PAPER SERIES

\title{
DOES FACTOR-BIASED TECHNOLOGICAL CHANGE STIFLE INTERNATIONAL CONVERGENCE? \\ EVIDENCE FROM MANUFACTURING
}

\author{
Eli Berman
}

Working Paper 7964

http://www.nber.org/papers/w7964

\author{
NATIONAL BUREAU OF ECONOMIC RESEARCH \\ 1050 Massachusetts Avenue \\ Cambridge, MA 02138 \\ October 2000
}

I acknowledge the helpful comments of Robert Barro, Francesco Caselli, Simon Gilchrist, Sam Kortum, Kevin Lang, Dilip Mookherjee and Andrew Weiss; seminar participants at Boston University, Case Western Reserve University, NBER Labor Studies and Productivity sessions, including my discussant at the last, Daron Acemoglu. This work continues research with Steve Machin during which a version of these data were prepared. I thank Valerie Frizzle for inspiring me to take chances, make mistakes and get messy. Mistakes are my own. The views expressed in this paper are those of the author and not necessarily those of the National Bureau of Economic Research.

(C) 2000 by Eli Berman. All rights reserved. Short sections of text, not to exceed two paragraphs, may be quoted without explicit permission provided that full credit, including (C) notice, is given to the source. 
Does Factor-Biased Technological Change Stifle International

Convergence? Evidence from Manufacturing

Eli Berman

NBER Working Paper No. 7964

October 2000

JEL No. J3, L60, O14, O3, O4

\title{
$\underline{\text { ABSTRACT }}$
}

Factor-biased technological change implies divergent productivity growth across countries with different amounts of skill and capital per worker. I estimate the extent of factor bias within industries and countries using a 19-country panel of manufacturing data covering the 1980s. Estimates using both production functions and total factor productivity functions show that technological change is strongly biased against less-skilled workers and toward both skilled workers and capital. An industry or country with twice the capital and skill per less-skilled worker enjoys $1.4 \%-1.8 \%$ faster total factor productivity growth annually due to the effects of factor-bias. These results are consistent

with the empirical literature on skill-biased technological change. They may well explain why "conditional convergence" of per capita income across countries is so slow.

\author{
Eli Berman \\ Department of Economics \\ Boston University \\ 270 Bay State Rd. \\ Boston, MA 02215 \\ and NBER \\ eli@bu.edu \\ http: \lecon.bu.eduleli \\ 617-353-6324
}




\section{INTRODUCTION}

Why do some countries remain so much poorer than others? The two basic approaches to income convergence yield quite hopeful conclusions. The factor accumulation approach [Solow 1956] explains that low productivity is the result of low ratios of skill and capital to labor. In the presence of diminishing returns, countries with low skill and capital intensity have highly productive skill and capital. That implies relatively rapid accumulation of capital and skill per worker in poor countries, eventual convergence in factor intensities and thus convergence in labor productivity. A second approach argues that low labor productivity is the result of using inferior technologies. ${ }^{1}$ Replicating technology must be less costly than inventing new technologies, so technology use should converge, leading to eventual convergence of total factor productivity.

The evidence, on the other hand, is not hopeful at all. Growth rates of GDP/capita are not generally higher in countries with low GDP/capita (at least since the early 1960s) [Barro 1991]. Most studies find convergence only after conditioning on available measures of international differences in institutions and preferences that explain the slow accumulation of skill and capital in poorer countries [Barro and Sala-I-Martin 1995, Mankiw, Romer and Weil1992]. Even then, this "conditional convergence" is quite slow.

This paper suggests an alternative explanation for slow productivity convergence: Factorbiased technological change. That mechanism has been quite successful in explaining increased returns to schooling in the U.S. and the shift in labor demand away from less educated workers and toward the more educated in the OECD. Substantial evidence now exists demonstrating that technological change has favored skilled (more educated) workers over less skilled (less educated)

1 Solow [1957] measures the extent of total factor productivity growth in the U.S. Eaton and Kortum [1996,1999] offer evidence of international technology transfer using R\&D and patent statistics. Technology transfer models fall into two broad categories. The "appropriate" technology model (Schumacher [1973]; Basu \& Weil [1998] ) posits that new technologies are not absorbed immediately in developing countries because of a lack of human or physical capital, differences in production technologies in use, or differences in factor prices. In contrast, the conventional assumption in growth theory is of pervasive technology in use everywhere. A weaker assumption is that technologies differ, but recent innovations are so efficient that they are adopted across a wide range of industries, factor price combinations and local technological capabilities. That concept is related to recent work on "General Purpose Technologies" [Bresnahan and Trajchtenberg, 1995; Helpman 1998], such as electrification and information technology which increase productivity in a wide range of industries. 
workers at least for the past few decades in many other parts of the world. ${ }^{2}$ Table 1 provides a sampling of that evidence, showing the declining wagebill shares of production workers in the manufacturing industries of both high and middle income countries.

The connection between factor bias and slow productivity growth is intuitive. If technology favors the skilled over the unskilled, then we would expect industries with more skilled workers to have faster total factor productivity (TFP) growth rates [Klenow 1998; Kahn and Lim 1998]. Similarly, it would not be surprising if countries with a high proportion of lessskilled workers had slower growth rates of income per capita. That basic insight is not new. It formed the motivation for previous work investigating skill-bias in developing countries [Berman and Machin 2000] and is developed quite fully in the induced technological change model of Acemoglu and Zilibotti [2000] to explain productivity differences across countries. ${ }^{3}$ The contribution of this paper is in developing that argument in a very general setting and in estimating the extent to which factor bias can slow productivity convergence.

This paper estimates the factor bias of technological change and applies the estimates to the puzzle of slow productivity convergence. The data are a three dimensional panel of industries over time for nineteen countries in the 1980s. Factor-bias parameters are estimated twice: in both a production function and a TFP function. Both approaches yield consistent, strong evidence that technological change favored both skilled labor and capital over unskilled labor. That conclusion is robust to a number of alternative approaches and specifications. Factor bias estimates indicate

${ }^{2}$ For evidence of recent skill-biased technological change in the U.S. see: Bound and Johnson, [1992]; Katz and Murphy, [1992]; Lawrence and Slaughter, [1993]; Berman, Bound, and Griliches, [1994]. Historical evidence is offered by Goldin and Katz [1996, 1998], as far back as the beginning of the century. Evidence from other OECD countries is available in Freeman [1988], Freeman and Katz [1994], Katz and Revenga [1989], Katz, Loveman and Blanchflower [1995], Davis [1992], Berman, Bound and Machin [1998]. Several studies have found increased relative wages of skilled labor in several developing countries despite widespread trade liberalization in the 1980s which would predict the opposite through the Stolper-Samuelson mechanism [Feliciano, 1995; Hanson and Harrison, 1995; Robbins, 1995; Berman, Bound and Machin, 1998; Berman and Machin, 2000.].

${ }^{3}$ That paper develops a theory of endogenous skill-bias in technological change. Their assumptions imply that the difference in measured TFP levels between developed and developing countries will be greater for unskill-intensive industries than for the skill-intensive. Their estimates, which draw on the same dataset as this paper does, find that pattern, but data limitations cannot allow them to tell if that is evidence of skill-bias or of some change in preferences. 
that an industry or a country with twice the ratio of skills and capital to less-skilled labor enjoys a $1.4 \%-1.8 \%$ faster annual rate of TFP growth.

The next section of this paper provides background about the lack of productivity convergence in the world, in the sampled countries and in their manufacturing industries. Section 3 develops a production function framework for estimation. Section 4 describes the data, deals with potential estimation problems, presents estimates and discusses their plausibility in the context of a world with accelerated technology-transfer. The fifth section examines the implications of estimated factor-bias for productivity convergence. Section 6 concludes.

\section{TFP GROWTH AND FACTOR ACCUMUlation IN MANUFACTURING}

Figure 1 looks at the manufacturing sample in the context of global nonconvergence, to check the representativeness of the data. The top panel, $1 \mathrm{~A}$, reproduces the standard finding that income per capita growth rates between 1960 and 1990 are uncorrelated with income levels [Barro 1991]. (Data are drawn from the Penn World Tables, version 5.6). The developing world shows higher variance in growth rates, but the same mean.

That international pattern of nonconvergence is quite stable. Figure $1 \mathrm{~B}$ plots the same relationship for 1980-90, revealing that the 1980s show the same pattern of nonconvergence, - a triangle pointing right.

The sample of manufacturing data used in this paper is drawn from the nineteen countries labeled in Figure 1B. They are a subsample of middle and high income countries used in previous work, further selected on having usable measures of capital at the beginning and end of the 1980s. Selection on data quality results in a disproportionate number of high income countries. Nevertheless, the relationship in the sample between growth and levels of GDP/capita roughly mimics the pattern in the larger sample: the cross-country variance of growth rates declines with income and the average growth rate shows a slight reduction as income increases. National growth rates are quite persistent. The correlation between the 1960-90 growth rate and the 198090 growth rate is $0.88(\alpha=0.00)$ for these nineteen countries. 
Figure $1 \mathrm{C}$ plots growth rates in manufacturing value added/worker against levels of GDP/capita for the nineteen country sample. This relationship shows the same triangle. Growth rates do not decline with income and have higher variance at lower income levels. Countries with high growth rates in GDP/capita generally have high growth rates in manufacturing value added per worker, though Portugal and Chile are exceptions. The correlation between the thirty year GDP/capita growth rate and the value added per worker rate in the 1980 s is $0.22(\alpha=0.38)$, but rises to $0.42(\alpha=0.08)$ without Chile. Overall manufacturing value added per worker in this sample mimics the pattern of nonconvergence in international GDP/capita. This is consistent with the conventional view that successful NICS, such as Korea, have grown by rapidly expanding manufacturing.

Is it factor accumulation or TFP that is not converging in manufacturing? Within the nineteen countries a careful decomposition of growth rates is possible into TFP growth on the one hand and factor accumulation (skill and capital intensity) on the other. Assume a production function $\mathrm{Y}=\mathrm{AF}(\mathrm{L}, \mathrm{S}, \mathrm{K})$ using unskilled labor, skilled labor and capital respectively. Assume constant returns and competitive markets to develop a standard definition of TFP growth:

$$
\Delta T F P=\Delta y-\left(\psi_{l} \Delta l+\psi_{s} \Delta s+\left(1-\psi_{l}-\psi_{s}\right) \Delta k\right)
$$

where lowercase letters are logarithms and $\psi$ 's are factor shares. Now let E (= L + S ) denote employment and develop the decomposition for the growth rate of value added per worker,

$$
\begin{gathered}
\Delta y-\Delta e=\psi_{l}(\Delta l-\Delta e)+\psi_{s}(\Delta s-\Delta e)+\left(1-\psi_{l}-\psi_{s}\right)(\Delta k-\Delta e)+\Delta T F P \\
=\text { "factor accumulation" }+\Delta T F P .
\end{gathered}
$$

Figure 2 illustrates that decomposition, with the left figure plotting factor accumulation against GDP/capita, and the right panel plotting TFP growth against GDP/capita. The left panel makes it clear that little Solow convergence occurred in the form of capital or skill accumulation. That pattern is analogous to the results of Mankiw, Romer and Weil (1992), who found convergence only once they conditioned on accumulation rates.

The right panel clearly illustrates that most of the variance in the growth of manufacturing value added per worker $(86 \%)$ is in TFP growth. It is worth stressing that since TFP growth rates are calculated as a residual, improved measurement might reallocate growth from TFP to 
factor accumulation. That was the case in the study by Griliches and Jorgenson [1967] of U.S. TFP growth, and in Young's [1995] study of TFP growth Hong Kong, Singapore, South Korea and Taiwan. ${ }^{4}$ On the other hand, these measured TFP growth rates for manufacturing are not simply measurement error. The correlation between the 1960-1990 GDP/capita growth rate and the manufacturing TFP growth rate in the 1980s is $0.17(\alpha=0.50)$, but rises to $0.42(\alpha=0.095)$ without Chile. That correlation is remarkably tight, considering the difference in data sources and fact that the two growth rates have only ten of thirty years in common. It is safe to conclude that a large component of growth in manufacturing output per worker is TFP growth. Furthermore, factor accumulation would have to be understated by an order of magnitude, and disproportionately so in the low income economies, for the basic picture in Figures $2 \mathrm{~A}$ and $2 \mathrm{~B}$ to be reversed.

Manufacturing TFP growth is not contributing to convergence either: it shows the same triangular pattern that observed in Figure 1 for manufacturing value added per worker and for GDP per capita.

To sum up, the manufacturing data reproduce the pattern of nonconvergence evident in GDP per capita. They reveal that most of the nonconvergence is in TFP growth rates. So if replication is less costly than invention, why is TFP growth not contributing to convergence in value added per worker? We need a theory of TFP divergence.

${ }^{4}$ Young [1995] addresses a debate as to whether the rapid growth of several East Asian economies is due to TFP growth or to factor accumulation. One of the messages of this paper is that the dichotomy is false, since factor bias translates current factor accumulation into future TFP growth. 


\section{Factor-Biased Technological Change in Production: A FRAMEWORK FOR ESTIMATION}

This section develops a framework to explain how factor-biased technological change can yield divergent TFP growth rates. That framework also generates estimating equations, allowing the data to report the magnitude of TFP divergence due to factor bias.

A Cobb-Douglas production function with exponents that change over time allows the possibility of factor-biased technological change,

$$
Y=e^{(\alpha+\rho t)} K^{\beta_{k}(t)} S^{\beta_{s}(t)} L^{\beta_{(t)}} .
$$

Here $\mathrm{Y}$ is product, $\mathrm{K}$ capital, $\mathrm{S}$ skilled labor and $\mathrm{L}$ unskilled labor. Time is indexed by $\mathrm{t}$.

The logarithmic form is convenient for discussing factor bias. Rewritten using lowercase letters to indicate logarithms, the production function is

$$
y=\alpha+\rho t+\beta_{k}(t) k+\beta_{s}(t) s+\beta_{l}(t) l .
$$

Output elasticities of factors are given by

$$
\frac{\partial y}{\partial f}=\beta_{f}(t) \quad \text { for } f \epsilon(k, s, l) \text {. }
$$

The rate at which $\beta_{\mathrm{f}}(\mathrm{t})$ changes bias of technological change towards factor $f$,

$$
\frac{\partial^{2} y}{\partial f \partial t}=\frac{\partial \beta_{f}(t)}{\partial t} \equiv \beta_{f}^{\prime}
$$

Constant returns to scale require that the exponents sum to one. A weaker assumption that proves to be useful is that returns to scale (constant or otherwise) remain unchanged by technological progress, or that the three $\beta_{\mathrm{f}}^{\prime}$ terms sum to zero. Call that assumption "unchanging returns to scale" (URS). I will discuss its implications below. ${ }^{5}$

A working definition of relative factor-bias helps to link this framework to the literature.

(3) Technological change is relatively skill biased if $\frac{\beta_{s}^{\prime}}{\beta_{s}(t)}>\frac{\beta_{l}^{\prime}}{\beta_{l}(t)}$.

${ }^{5}$ If inputs are to be forever useful in production and subject to diminishing marginal returns, then the standard restriction $0<\beta_{\mathrm{f}}(\mathrm{t})<1$ must also be imposed for all factors $\mathrm{f}$ and time $\mathrm{t}$. 
In words, relative skill bias exists if the output elasticity of skilled labor increases at a faster rate than that of unskilled labor. To justify that usage, consider the implications of relative skill-bias. Assuming perfectly competitive labor markets, (3) implies that, holding relative wages constant, the relative demand for skilled workers increases with time, since

$$
\frac{w_{s}}{w_{l}}=\frac{M P_{s}}{M P_{l}}=\frac{\beta_{s}(t)(Y / S)}{\beta_{l}(t)(Y / L)}=\frac{\beta_{s}(t)}{\beta_{l}(t)} \frac{L}{S}, \text { so that } \frac{S}{L}=\frac{\beta_{s}(t)}{\beta_{l}(t)} \frac{w_{l}}{w_{s}}
$$

Conversely, holding the ratio of inputs fixed inputs fixed, relative skill-bias implies that the relative wage of skilled workers increases. For this production function, it also implies that the wagebill share of skilled workers increases. These three implications have been treated as alternative symptoms of skill-biased technological change in the literature. ${ }^{6}$

This framework allows estimation of the absolute (as opposed to the relative) bias of technological change.

Define technological change as

absolutely $f$-biased if $\beta_{\mathrm{f}}^{\prime}>0$, and

(4) absolutely $f$-saving if $\beta^{\prime}<0$,

for $f \in(l, s, k)$.

That is, technological change is absolutely f-biased if the marginal product of factor $\mathrm{f}$ increases (beyond the neutral increase, $\rho$ ), holding inputs constant.

In the two factor model with unchanging returns to scale $\beta^{\prime}{ }_{s}=-\beta^{\prime}{ }_{1}$, so absolute and relative skill bias are equivalent, and skill-biased technological change is equivalent to labor-saving technological change.

The three factor model, even with unchanging returns to scale, is more flexible. For instance, technology could be absolutely biased against both $s$ and $l$, but relatively biased toward $s$. Assuming unchanging returns, absolute skill-bias and absolute capital-bias imply absolute labor-saving technological change, since $\beta_{1}^{\prime}=-\beta_{\mathrm{k}}^{\prime}-\beta_{\mathrm{s}}^{\prime}$.

\footnotetext{
${ }^{6}$ For example, Bound and Johnson [1992] or Katz and Murphy [1992].
} 


\section{Factor Bias and Productivity Growth}

To study the effect of factor bias on productivity change, note that the $\beta^{\prime}$ terms also reflect the effect of factor quantities on changes in total factor productivity. To see this, note that

$$
\frac{d T F P}{d t} \equiv \frac{\partial y}{\partial t}=\rho+\left(\beta_{k}^{\prime} k+\beta_{s}^{\prime} s+\beta_{l}^{\prime} l\right) \text { and } \frac{\partial^{2} y}{\partial t \partial f}=\beta_{f}^{\prime} \text {. }
$$

Here the partial derivative of y with respect to time is a change in total factor productivity, since inputs are held constant. The cross partial of product with respect to time and input $f$ is the factorbias term. For example, if technological change is absolutely skill biased, then TFP growth must be faster, the greater the level of skilled labor in production. That property is not particular to the Cobb-Douglas form. It follows from the symmetry of cross-partial derivatives in any production function. Equation (5) indicates one way of estimating factor bias terms, by regressing the TFP growth rate on the levels of inputs.

Figure 3 illustrates a relatively skill-biased technological change as the shift of an isoquant in S, L space, holding $\mathrm{K}$ constant. For a country or an industry at point $\mathrm{B}$, with the $\mathrm{S} / \mathrm{L}$ ratio given by the slope of the vector $\mathrm{OB}$, the productivity gain is given by length of the segment $\mathrm{BC}$--the decrease in inputs required to produce a unit of output. That technological change is relatively skill-biased since, at the relative wage illustrated by the slope of the line tangent to the isoquant at $\mathrm{B}$, the new isoquant requires a higher $\mathrm{S} / \mathrm{L}$ ratio (at point $\mathrm{D}$ ). In contrast, a country or industry with the lower S/L ratio given by the vector OA experiences no productivity gain. The size of the differential productivity gain between A and B is given by the factor bias coefficients (the $\beta^{\prime}$ ), which are estimated below.

Assuming unchanging returns to scale, $\beta^{\prime}$ has the following convenient interpretation: If one industry has twice the $\mathrm{K} / \mathrm{L}$ ratio and twice the $\mathrm{S} / \mathrm{L}$ ratio as another, the TFP growth rate of the former will be $-\beta^{\prime}{ }_{1}$ faster. Anticipating the results, $\beta^{\prime}{ }_{1}$ will be negative, so the former will grow faster.

The unchanging returns assumption is not critical for what follows. It is convenient though, and allows for more precise estimates. Is it a reasonable assumption? The data will insist that the factor bias terms (the $\beta_{\mathrm{f}}^{\prime}$ ) sum to a negative number, implying that returns to scale decline over time. Yet there is a replication argument that returns to scale should remain unchanging. 
Without URS, scale would affect the TFP growth rate of an industry (see equation (5)). If declining returns were true at the firm level, large firms could split into smaller pieces to increase productivity. If declining returns were true at the industry level, large industries could send production abroad to increase productivity. Either way, in equilibrium we should not observe declining returns to scale. The plausibility of URS will come up again in interpreting estimates, though the thrust of the evidence for factor bias will not require this assumption.

\section{Measurement Issues and Estimating Equations}

Estimation requires a functional form for $\beta(t)$. Impose the restriction ${ }^{7}$

$$
\beta_{\mathrm{f}}(\mathrm{t})=\beta_{\mathrm{f}}+\gamma_{\mathrm{f}} \mathrm{t} \text {, so that } \beta_{\mathrm{f}}^{\prime}=\gamma_{\mathrm{f}} \text {. }
$$

Substituting that restriction into (2) yields one way of estimating factor-bias terms. Equation (5) provides a second method. The data available to estimate the parameters of the production function (equation (1)) are a three-dimensional panel of manufacturing industries within countries observed twice, at the beginning and end of the 1980s.

Measurement issues complicate estimation for two reasons. First, inputs are measured inconsistently. The definitions of skilled and unskilled labor are likely to differ conceptually across countries. For instance, middle income countries are more likely to undersample small firms, which tend to have lower proportions of skilled workers, leading them to overestimate the proportion of skilled workers. ${ }^{8}$ The quality of all three inputs may also differ across industries. More generally, we know from the work of Griliches and Jorgenson [1967], that mismeasurement of input quality can lead to substantial mistakes in TFP accounting. Assume that capital, skilled labor and unskilled labor are measured with a country-specific error of proportionality. In logarithms, the measured quantity is then the sum of the true quantity and a country-factor specific error,

${ }^{7}$ This restriction should be thought of as a short term approximation. The linear functional form implies that if $\gamma_{\mathrm{f}}$ is nonzero, factor $f$ will eventually have an output elasticity outside the [0,1] interval.

${ }^{8}$ For example, the measured proportion of skilled workers in Japanese manufacturing jumped from 46 to 53 percent between the 1975 and 1978 surveys when the minimum firm size which got the "long form" with the skilled worker question changed. 


$$
f^{n}{ }_{i c t}=f_{i c t}+u_{c}^{f} \quad \text { for } f \in(k, s, l) \text {. }
$$

Besides inconsistent measurement of factor qualities, a second source of likely measurement error is in price comparisons across countries and industries. National price indexes (from the Penn World Tables) are not completely corrected for quality, which is likely to differ disproportionately across industries because of market power, particularly for nontraded goods. These fixed industry-country specific price differences are absorbed by an industry-country specific level effect, $\alpha_{i c}$, which also absorbs fixed productivity differences, measurement error in output and any industry-country specific measurement error in quantities. These measurement errors may be substantial considering that the data are collected from disparate sources without the intention of making them comparable. I also include a country-period specific productivity level $\delta_{\mathrm{ct}}$, and an industry specific productivity trend in output growth $\rho_{\mathrm{i}}$. With these additions, substituting (6) into (2) yields

$$
\begin{aligned}
y_{i c t} & =\alpha_{i c}+\delta_{c t}+\beta_{k}\left(k_{i c t}+u_{c}^{k}\right)+\beta_{s}\left(s_{i c t}+u_{c}^{s}\right)+\beta_{l}\left(l_{i c t}+u_{c}^{l}\right) \\
& +\rho_{i} t+\left(\gamma_{k}\left(k_{i c t}+u_{c}^{k}\right)+\gamma_{s}\left(s_{i c t}+u_{c}^{s}\right)+\gamma_{l}\left(l_{i c t}+u_{c}^{l}\right)\right) t+\epsilon_{i c t} .
\end{aligned}
$$

Differencing (7) over time removes the time-invariant measurement error from $\beta$ coefficients but not from $\gamma$ coefficients. Labeling the periods $t=0$ and $t=1$ and defining $\Delta x_{i c t}=x_{i c l}-x_{i c c},($ for a generic variable $x)$

$$
\begin{aligned}
\Delta y_{i c} & =\beta_{k} \Delta k_{i c}+\beta_{s} \Delta s_{i c}+\beta_{l} \Delta l_{i c}+\gamma_{k} k_{i c}+\gamma_{s} s_{i c}+\gamma_{l} l_{i c} \\
& +\rho_{i}+\left[\Delta \delta_{c}+\gamma_{k} u_{c}^{k}+\gamma_{s} u_{c}^{s}+\gamma_{l} u_{c}^{l}\right]+\Delta \epsilon_{i c} .
\end{aligned}
$$

Under these assumptions the elasticity coefficients $\beta$ and the factor-bias coefficients $\gamma$ are identified despite the measurement error. The estimated country effect includes all the bracketed terms: the country-specific change in productivity $\Delta \delta_{c}$ and terms involving country-specific measurement error in factors. There is a symmetric argument for industry-factor specific measurement error, $u_{i}^{f}$, which can be accommodated in the same way, compromising 
identification of industry specific changes in productivity, $\rho_{\mathrm{i}}$, but not affecting identification of the elasticities and factor bias terms.

One final measurement problem is that physical units of value added are not actually observed. I can measure PY (sales net of intermediate inputs), or $p+y$ in logarithms. This is a familiar problem in production function estimation whenever the price deflator is suspect, but the ability to estimate industry effects adds a novel element to the solution. Consider the reduced form regression of $\Delta p$ on $\Delta y$ (which cannot be run for lack of data),

$$
\Delta p_{\mathrm{ic}}=a_{i}+b_{c}+m \Delta y_{i c}+v_{i c} .
$$

Here $a_{i}$ and $b_{c}$ are industry and country fixed effects in price changes. The coefficient $m$ cannot be signed. Using a textbook simultaneity bias calculation, it is an average of the (inverse) demand and supply elasticities of industry output, weighted by the variances of demand and supply shifts. Since those variances are conditional on common industry effects across countries, they can be interpreted as local supply and demand shifts. For instance, $m$ will be positive if the variance of local demand shifts exceeds that of local supply shifts and the price elasticity of demand exceeds that of supply (in absolute value). Conditional on industry effects, $m$ would be quite small if trade makes product demand quite elastic. In the estimates reported below, $m$ will in fact be quite small.

Adding $\Delta p$ to both sides of (8) and substituting for $\Delta p$ on the right hand side from (9) yields

$$
\begin{aligned}
\Delta p_{i c}+\Delta y_{i c}= & \Delta p_{i c}+\beta_{k} \Delta k_{i c}+\beta_{s} \Delta s_{i c}+\beta_{l} \Delta l_{i c}+\gamma_{k} k_{i c}+\gamma_{s} s_{i c}+\gamma_{l} l_{i c} \\
& +\rho_{i}+\left[\Delta \delta_{c}+\gamma_{k} u_{c}^{k}+\gamma_{s} u_{c}^{s}+\gamma_{l} u_{c}^{l}\right]+\Delta \epsilon_{i c} \\
= & (1+m)\left(\beta_{k} \Delta k_{i c}+\beta_{s} \Delta s_{i c}+\beta_{l} \Delta l_{i c}+\gamma_{k} k_{i c}+\gamma_{s} s_{i c}+\gamma_{l} l_{i c}\right. \\
& \left.\quad \rho_{i}+\left[\Delta \delta_{c}+\gamma_{k} u_{c}^{k}+\gamma_{s} u_{c}^{s}+\gamma_{l} u_{c}^{l}\right]+\Delta \epsilon_{i c}\right) \\
& +a_{i}+b_{c}+v_{i c} .
\end{aligned}
$$

Thus, unmeasured price changes introduces an ambiguity. The coefficients of (8) are identified only up to a proportion $(1+m)$ : $(1+m) \beta_{\mathrm{f}},(1+m) \gamma_{\mathrm{f}}$ for factors $f \in(l, s, k)$. The extent of that distortion $(1+m)$ can be estimated if constant returns are assumed. Then the sum of estimated $\beta$ 
coefficients is, $\sum_{f}(1+m) \beta_{f}=(1+m)$. Note that industry and country effects in price changes from (9) will also be loaded onto the estimated industry and country effects.

\section{TFP Specification}

An alternative approach to estimating the factor-bias terms is to use the relationship in (5), regressing dTFP on input levels. ${ }^{9}$ This approach requires making standard assumptions in order to calculate factor weights in TFP - constant returns and competitive markets. On the other hand, it allows much more flexibility in the production function. The time invariant part is not restricted to have a Cobb-Douglas form, to have a constant elasticity of substitution between factors or to have common parameters in different industries and countries.

Assuming constant returns to scale and competitive markets, the value-added shares of each factor, $\psi$, provide factor weights in calculating the rate of TFP change,

$$
\begin{aligned}
\frac{d T F P}{d t} & =\Delta y_{i c}-\psi_{i c}^{k} \Delta k_{i c}-\psi_{i c}^{s} \Delta s_{i c}-\psi_{i c}^{l} \Delta l_{i c} \\
& =\gamma_{k} k_{i c}+\gamma_{s} s_{i c}+\gamma_{l} l_{i c}+\rho_{i}+\left[\Delta \delta_{c}+\gamma_{k} u_{c}^{k}+\gamma_{s} u_{c}^{s}+\gamma_{l} u_{c}^{l}\right]+\Delta \epsilon_{i c} .
\end{aligned}
$$

The factor-bias portion of the remainder of the equation is specified as in (8), allowing separate trends of biased technological change for each factor. Factor bias coefficients are identified up to a multiplicative constant $(1+m)$, as in (10). Similarly, estimated country and industry effects in productivity change capture country and industry-specific price changes as well as country and industry-specific measurement error in factors (though the equation only illustrates this point for the country effect).

The following section estimates factor bias terms using both Cobb-Douglas and TFP specifications.

${ }^{9}$ This approach is similar to that taken by Kahn and Lim [1998] in their study of skill-augmenting technological change in the U.S. In their estimating equation the shares appear as covariates and they are forced to impose an adding up constraint on these, similar to URS. 


\section{RESUltS}

A rich three-dimensional panel of industries across countries over time is available to estimate the factor bias terms. Since it covers countries with industries at different levels of development, it contains unusually rich variation over time, industries and countries. This section describes the data, discusses potential biases in estimation and presents results.

\section{Data}

To investigate factor bias this paper uses the United Nations General Industrial Statistics Database [United Nations 1992] (later administered by UNIDO). It includes manufacturing employment, wagebill, investment and output data for many countries. This rich data set reflects the unique capability of the United Nations to compile data by soliciting contributions from the statistical agencies of member countries. ${ }^{10}$ It covers 28 manufacturing industries at (broadly) the two to three-digit level, consistently defined across countries and years using the ISIC classification. Countries were selected that provide data of consistent quality over time.

Table 2 reports descriptive statistics for the nineteen countries used. They are ranked by income, (all figures reported in constant 1985 dollars, using the GDP deflators and 1985 exchange rates from the Penn World Tables [Summers and Heston, 1991]. Following a classification used in previous work [Berman and Machin, 2000], countries are arranged into two income groups: a high income group with GDP per capita exceeding \$10,000 (1985 US\$) in 1980; and a middle income group with GDP per capita between \$2,000 and \$10,000 in 1980.

The ten middle income countries are from Asia, Europe and South America. This group includes several countries with large manufacturing sectors: (the former) Czechoslovakia, Korea, and Spain. The high income group includes nine countries ranging in income from Japan to the U.S. The choice of 1985 exchange rates favors the U.S., but note that U.S. value added per

\footnotetext{
${ }^{10}$ The main purpose of these data is to facilitate international comparisons relating to the manufacturing sector. Concepts and definitions are drawn from the International Recommendations for Industrial Statistics [Statistical Papers, Series M, No 48/Rev 1, United Nations Publication] and the classification by industry is taken from the International Standard Industrial Classification (ISIC) of All Economic Activities [Statistical Papers, Series M, No 4/Rev 2, United Nations]. For details see the Data Appendix in Berman, Bound and Machin [1998].
} 
worker is twice as high in 1980 as that of West Germany, the second-ranked country in this group. The U.S. is also the largest manufacturing employer, with $19 \mathrm{~m}$ workers, followed by Japan with $10.5 \mathrm{~m}$, the UK with $6.5 \mathrm{~m}$ and West Germany with $6.3 \mathrm{~m}$.

Our measure of skill in these data is the classification into nonproduction and production workers (operatives and nonoperatives in UN terminology). The term production worker usually refers to employees directly engaged in production or related activities of the establishment. That includes clerks or working supervisors whose function is to record or expedite any step in the production process. Employees of a similar type engaged in activities ancillary to the main activity of the establishment and those engaged in truck driving, repair and maintenance and so on, are also considered to be production workers.

This is far from the ideal measure of "skill," which would include elements of education and training. ${ }^{11}$ Clearly the educational level of each of these categories of worker differs across countries. Two sources of evidence indicate that nonproduction workers have higher educational attainment than production workers: 1) cross-tabulations of matched worker and employer surveys at the plant in the U.S. in 1990 reveal a fairly tight relationship between years of schooling, occupation and nonproduction categories ${ }^{12}$ [Berman, Bound and Machin, 1997]. An analogous effort at the industry level in the UK reveals a similar mapping [Machin, Ryan and Van Reenen, 1996]. Harris [1999] reports the results of a similar exercise at the plant level, which also reveal that nonproduction workers have a higher educational level;

2) Nonproduction workers are uniformly better paid. Quality indices based on a comparison of CPS and ASM data in the U.S. suggest that about $1 / 2$ of skill upgrading in U.S. manufacturing took place within nonproduction and production categories over the 1980s [Berman, Bound and Griliches, 1994]. We conclude that while the aggregation problems are worse than usual for these categories, within country comparisons are probably reasonable measures over periods as long as

\footnotetext{
${ }^{11}$ The term "skill" in skill-bias is an unfortunately vague expression we inherit from the literature. In our discussion "skill"can be interpreted as education.

1275 percent of nonproduction workers are in white collar occupations, while 81 percent of production workers are in blue collar occupations. 76 percent of nonproduction workers have at least some college education, while $61 \%$ of production workers have a high school education or less.
} 
a decade, while between country comparisons, especially across income ranges, should be viewed with caution.

Capital stock is calculated by summing and discounting lagged investment. These are discounted using the Penn World Tables investment price index. Discount factors and coefficients on lagged investment are fitted from the Gray-Bartelsman [1995] data on U.S. manufacturing, which reports both investment and capital stock. For details see Berman and Machin [2000].

Table 3 provides descriptive statistics for estimating equations. Total factor productivity growth is only slightly higher in our sample among middle income countries than among the developed countries. (The calculation of TFP growth is described in the next subsection.) The standard deviation is almost three times as high among middle income countries, reproducing the pattern in Figure 2 of selective convergence. Note also that manufacturing industries in high income countries have a much faster absolute decline in production worker employment.

\section{Potential Pitfalls in Estimation}

Estimation of (10) and (11) is complicated by several potential sources of bias familiar from the literature on the estimation of production functions [Griliches and Mairesse, 1995]. Before we get distracted by the estimates and the economics, let's turn to the dirty work of discussing potential biases and how they are treated.

First, measurement error is likely in the levels of factors, which is both transitory and industry-country specific, so that industry and country effects will not absorb it. This could be anything from fluctuations in unmeasured quality, to price changes in capital to coding error.

One implication of transitory measurement error is that it appears on both sides of equation (11), creating the potential for spurious correlation between factor levels and $\Delta \mathrm{TFP}$. To illustrate, let $f_{t}$ be a vector of measured factors in period $t$. Now

$$
\mathrm{f}_{\mathrm{t}}=\mathrm{f}_{\mathrm{t}}^{*}+\mathrm{u}_{\mathrm{t}} \text {, }
$$

where $f_{t}^{*}$ is the true level and $u_{t}$ is classical measurement error, uncorrelated with $f$ or $y$. The change in TFP would then be calculated as

$$
\Delta \mathrm{TFP}=\Delta \mathrm{y}-\psi^{\prime} \Delta \mathrm{f}=\Delta \mathrm{y}-\psi^{\prime} \Delta \mathrm{f}^{*}-\psi^{\prime}\left(\mathrm{u}_{\mathrm{t}}-\mathrm{u}_{\mathrm{t}-1}\right)=\Delta \mathrm{TFP}^{*}-\psi^{\prime}\left(\mathrm{u}_{\mathrm{t}}-\mathrm{u}_{\mathrm{t}-1}\right) .
$$


That measurement error would create a spurious negative correlation with $\mathrm{f}_{\mathrm{t}}$ and a spurious positive correlation with $\mathrm{f}_{\mathrm{t}-1}$.

A convenient solution is to use the average level of factors over time as a regressor (consistent with the approximation of the derivative with respect to time in equation (11)). Let $\mathrm{f}=\left(\mathrm{f}_{\mathrm{t}}+\mathrm{f}_{\mathrm{t}-1}\right) / 2=\mathrm{f}^{*}+\left(\mathrm{u}_{\mathrm{t}}+\mathrm{u}_{\mathrm{t}-1}\right) / 2$. Let $\Sigma_{\mathrm{t}}$ denote the variance of $\mathrm{u}_{\mathrm{t}}$. The spurious covariance $\psi^{\prime} \operatorname{Cov}\left(\mathrm{u}_{\mathrm{t}}-\mathrm{u}_{\mathrm{t}-1}, \mathrm{u}_{\mathrm{t}}-\mathrm{u}_{\mathrm{t}-1}\right) \psi / 2=\psi^{\prime}\left(\Sigma_{\mathrm{t}}-\Sigma_{\mathrm{t}-1}\right) \psi / 2$, which will be zero if the variance of the measurement error is unchanged over time.

A related problem arises with the shares $\psi^{\mathrm{f}}=\mathrm{w}^{\mathrm{f}} \mathrm{F} / \mathrm{Y}$ (where $\mathrm{w}^{\mathrm{f}} \mathrm{F}$ is the wagebill of factor $\mathrm{f}$, and capital's share is calculated as a residual). These include the level of factor F on the left-hand side of (11). So transitory measurement error appears in levels on the left-hand side and in logarithm on the right-hand side, inducing a spurious correlation. That spurious correlation is prevented by predicting $\psi_{\text {ic }}$ using a regression of shares on industry and country indicators and using the predicted values to calculate TFP. These predicted values are then purged of industrycountry specific measurement error.

A second, more standard, implication of measurement error in factors of production is that bias due to measurement error is exacerbated by differencing, because of the reduction in the signal to noise ratio (the ratio of the true variance to the variance of the measurement error). So we expect the estimated elasticities (the $\beta$ 's) in equation (10) to be biased downward. This is a common problem in estimating production functions in differences. The estimated capital coefficient in firm data is often near zero [Griliches and Mairesse 1995].

The potentially biased $\beta$ estimates are for the most part incidental, but they could transmit bias to the estimated $\gamma$ terms through the covariance of estimated coefficients. To see this, consider the least squares regression estimating vectors $\beta$ and $\gamma$, where $X_{1}=\Delta \mathrm{f}$, and $X_{2}=f$, assuming that $\Delta \mathrm{f}$ is correlated with the error term, but $\mathrm{f}$ is not. The least squares estimator is then

$$
\begin{aligned}
{\left[\begin{array}{l}
b \\
g
\end{array}\right] } & =\left(X^{\prime} X\right)^{-1} X^{\prime}\left[X_{1} \beta+X_{2} \gamma+\epsilon\right] \\
\text { so }\left[\begin{array}{c}
b-\beta \\
g-\gamma
\end{array}\right] & =\left(X^{\prime} X\right)^{-1}\left[\begin{array}{l}
X_{1}^{\prime} \epsilon \\
X_{2}^{\prime} \epsilon
\end{array}\right]=\left[\begin{array}{ll}
A & B \\
C & D
\end{array}\right]\left[\begin{array}{l}
X_{1}^{\prime} \epsilon \\
X_{2}^{\prime} \epsilon
\end{array}\right] \\
\text { Assume } E\left(X_{1}^{\prime} \epsilon \mid X\right) & =a, \text { and } E\left(X_{2}^{\prime} \epsilon \mid X\right)=0 . \\
\text { Then } E(b-\beta \mid X) & =A a \\
\text { and } E(g-\gamma \mid X) & =C a=C A^{-1} E(b-\beta \mid X) \\
& =\operatorname{Cov}\left(g, b^{\prime}\right) V(b)^{-1} E(8-\beta \mid X) \text { under homoskedastic errors. }
\end{aligned}
$$


Aggregation to the industry level helps in this respect, as measurement error between firms tends to cancel, raising the ratio of signal to noise. The developing country data also seem to be rich in signal, as we shall see below. Defining $\mathrm{f}$ as an average over time also helps. It reduces the spurious negative covariance of $\Delta \mathrm{f}$ with $\mathrm{f}$ due to measurement error, thus reducing the spurious covariance between estimated $\beta$ and $\gamma$ coefficients. A third treatment is to use prior beliefs about the values of $\beta$ 's to bound the possible bias on $\gamma$. This last idea can be best explained by demonstration.

A third potential source of bias is an endogenous response of factor use $\Delta \mathrm{f}$, to an industry-country specific change in productivity or prices. That would induce a positive covariance with the error term, $\operatorname{Cov}(\Delta \mathrm{f}, \Delta \epsilon)>0$, and a generally upward bias in the estimated $\beta$ in equation (10). As before, experimenting with restrictions on the estimated $\beta$ can help gauge how much bias is transmitted to the estimated $\gamma$.

A related concern is that endogenous response will induce a positive correlation between the measured level of $\mathrm{f}$ and the error term, $\operatorname{Cov}(\mathrm{f}, \Delta \epsilon)>0$, since $\mathrm{f}_{\mathrm{t}}$ appears in $\mathrm{f}$. That problem can be treated in the production function specification by using lagged inputs $\mathrm{f}_{\mathrm{t}-1}$ as instruments, since they are determined before $\Delta \epsilon_{\mathrm{t}}$ is observed. ${ }^{13}$ Thus, identification of the $\gamma$ terms in equation (10) comes from cross-industry variation in the lagged levels of inputs (s, l, k) which could arise from any number of historical, industry-country specific, demand or supply conditions in labor, capital, or product markets.

This endogeneity bias is more serious in the TFP specification, since lagged values of inputs are not valid instruments. There, in the presence of transitory measurement error, the error term will include $-\psi^{`}\left(u_{t}-u_{t-1}\right)$. Thus, instrumenting with the variable $f_{t-1}$, which includes the lagged measurement error $\mathrm{u}_{\mathrm{t}-1}$, will tend to bias the estimated $\gamma$ away from zero (in addition to any bias due to classical measurement error, probably toward zero.)

${ }^{13}$ Strictly speaking, that instrument will be invalid in the production function specification, since $\operatorname{Cov}\left(u_{t-1},\left[u_{t}+u_{t-1}\right] / 2\right)>0$, where $u_{t}$ is the measurement error in measuring the factors $f_{t}$. Nevertheless, the induced bias is probably no worse than the standard least squares attenuation bias (which involves the covariance of $\left(\mathrm{u}_{\mathrm{t}}+\mathrm{u}_{\mathrm{t}-1}\right) / 2$ with itself, but also a larger denominator) and would likely tend only to bias estimates towards zero. 
In summary, identifying the factor-bias terms in the production function specification appears to be feasible, as the major sources of potential bias can be controlled. However, in the TFP specification, there is a potential endogeneity bias. In practice, comparing the results of the two approaches will turn out to be informative.

\section{Results}

Table 4 reports the result of estimating the translog specification in equation (10). The first three rows report the factor bias coefficients $(\gamma)$ on log levels of inputs, while the next three report the elasticities $(\beta)$ on changes in logarithms. As noted in the last section, bias in the estimated $\beta$ might be transmitted to the estimated $\gamma$. Looking first at the $\beta$ coefficients in the leftmost row, note that they are large, with an estimated $\beta_{\mathrm{k}}$ of .774 and returns to scale of 1.39 . This is not an unusual result in cross-country regressions with developing countries. It may be due to endogenous adjustment of inputs, especially capital, to price and productivity shocks. It may also be due to a positive correlation of prices and quantities of product, reflected in a positive $m$ coefficient in (9). Those excessive returns to scale recede when we include country effects. The estimated $\beta_{\mathrm{k}}$ declines to a more reasonable 0.448 . That change indicates that the high coefficient on $\Delta k$ in the leftmost column of results may have been due to country-specific, cyclical increases in measured productivity. The $\beta$ 's sum to 1.09 . Thus, if constant returns hold, the bias due to not measuring prices ( $m$ in equation (10)) is rather small - estimated coefficients are about $9 \%$ too high in absolute value. The reasonable size of the estimated $\beta$ 's from the "country effects" column on also provides some reassurance about bias in the estimated $\beta$ that may be transmitted to the estimated $\gamma$ coefficients.

The third column adds industry effects in productivity growth, as specified in equation (10). That does not much change the estimated $\beta$ 's. Under constant returns, $m$ is estimated at $8 \%$. The addition of industry effects corrects a positive omitted variable bias on the estimate of $\gamma_{1}$ in the previous column, changing it from $-1.24 \%$ to $-2.15 \%$. Conditional on country effects, industries with high production worker employment tended to have high measured TFP growth, 
implying a sector bias [Haskell and Slaughter 1998] toward unskilled workers ${ }^{14}$ (or at least industry-specific time-invariant measurement error in inputs).

Before turning to robustness checks, consider the economic interpretation of the factorbias coefficients. The estimated coefficient on production workers, $\gamma_{1}$, is $-2.15 \%$. Subtracting 0.16 due to $m$, this implies that annual productivity growth is almost $2 \%$ slower in industries with twice as many production workers. The estimated standard error is $(0.51)$, indicating strong evidence of absolute labor saving technological change.

The estimated coefficient on skilled labor, $\gamma_{s}$, is positive, at 0.69 , but not statistically significant, providing weak evidence of absolute skill bias. Evidence for relative skill-bias is strong, as the estimated value of $\gamma_{\mathrm{s}}-\gamma_{1}$ is $2.41 \%$ (s.e.=1.05\%) (not shown in the Table). The estimated coefficient on capital, $\gamma_{\mathrm{k}}$ is $0.87 \%(0.41 \%)$, providing strong evidence of absolute capital bias in technological change.

The second to last row reports the change in returns to scale $\gamma_{\mathrm{s}}+\gamma_{\mathrm{k}}+\gamma_{1}$, which would be zero under unchanging returns to scale (URS). The estimated sum is $-0.59 \%$, indicating that increased productivity of skilled labor and capital does not fully compensate for declining productivity of unskilled labor. (This does not imply a productivity decline, since the equation allows Hicks-neutral productivity change.) Changing returns to scale are an uncomfortable finding. They conflict with the replication argument offered in the previous section, since they imply that industries of different sizes have systematically different TFP growth rates. (In this case smaller industries have higher growth rates.) Those objections, and the clear interpretation that URS allows, argue for exploring what happens if URS is imposed. I will return to discuss the cost of the URS assumption in the next section.

To put these results in context (ignore the data's objections and) impose URS. That raises the estimated skill and capital bias coefficients, yielding an implied $\gamma_{1}$ estimate of $-1.80 \%$ (which is less negative than the unrestricted estimate), or $-1.67 \%$ corrected for $m$. In other words, conditional on industry and country effects, an industry with twice the capital/unskilled labor ratio and twice the skilled/unskilled labor ratio has an annual TFP growth advantage of $1.67 \%$ !

\footnotetext{
${ }^{14}$ In the analysis that follows that sector bias will be allowed to differ by income group.
} 
Are these results driven by some outlier, rogue industry or misbehaving country? Figure 4 illustrates a leverage plot of the estimated $\gamma_{1}$. It graphs the growth rate of value added against the $\log$ of production employment, once both have been conditioned on all the other covariates (in the linear regression sense). The Frisch-Waugh theorem implies that this slope is the same as that in the weighted, multivariate regression. The upper left panel is a simple scatterplot. The upper right panel is drawn with circles proportional to the weights used in the regression (value-added shares within country). The lower two panels are labeled by country and industry. Combined, the four panels make it clear that estimated labor-saving technological change is not driven by outliers. As a separate robustness check the regression was run dropping a single country each time. That had no substantial effect on the factor bias coefficients.

What about other potential pitfalls? Table 5 examines these. One potential source of bias is the endogenous reaction of factors $(1, s, k)$ to industry-country specific productivity or price changes, which would appear in the residual, $\Delta \epsilon$. Since factors are measured at their average level between the beginning and end of the period, this may bias estimated coefficients, probably towards one. Using lagged levels $\left(\mathrm{l}_{\mathrm{t}-1}, \mathrm{~s}_{\mathrm{t}-1}, \mathrm{k}_{\mathrm{t}-1}\right)$ as instrumental variables can treat that problem, since these are determined before a productivity or price shock. The column labeled "lagged levels as instruments" reports those instrumental variable estimates. These are essentially identical to the least squares estimates in the previous table. A Hausman test reveals that we cannot reject the hypothesis of identical coefficients: endogenous reaction of factors to productivity or price shocks is not a source of discernible bias.

Another potential source of bias discussed above is a bias transmitted from the $\beta$ coefficients to the $\gamma$ coefficients. (The $\beta$ coefficients are estimated without an instrument in all specifications so they are vulnerable to bias due to endogenous response to productivity or price shocks, for instance.) Regardless of the source of potential bias, the most suspicious estimated $\beta$ coefficient is that on log change in nonproduction workers. At 0.49 , it is much higher than the nonproduction wagebill share in value added. One way to approach the potential transmitted bias is to force that coefficient to take a lower value and observe the change in $\gamma$ estimates, (as suggested by the bias formula in the subsection above). A possible restriction would be constant returns to scale, which are imposed in the next column to the right. That exercise has little effect 
on the $\beta$ 's so it is not surprising that the $\gamma$ 's are not much changed. A more drastic step is to force the estimated $\beta_{\mathrm{s}}$ coefficient to be zero, in order to provide an upper bound on the possible transmitted bias. That reduces the estimated $\gamma_{\mathrm{s}}$ coefficient from 0.69 to 0.47 but has little effect on the other factor-bias coefficients. The URS-restricted $\gamma_{1}$ estimate rises from -1.80 to -1.64 , which can be thought of as an upper bound for the rate of labor saving technological change.

The main conclusions of Table 4 are robust to corrections for endogeneity and measurement error biases: very strong evidence that technological change had an absolute labor saving bias, weaker but statistically significant evidence of an absolute capital-bias, and evidence of absolute skill-bias on the borderline of statistical significance. Evidence of relative skill-bias is quite strong, which is consistent with the literature discussed in the introduction.

\section{TFP Function Estimates}

The total factor productivity specification is more flexible in many ways than the production function. It requires no functional form assumptions except on the factor bias terms. In particular, it does not impose unitary elasticity of substitution between factors. It does require the (standard) assumptions of constant returns to scale and competitive markets to define TFP. (Note that constant returns were not rejected in the specifications estimated in Table 3, except in the first, -which did not include country effects).

Table 6 reports estimated factor-bias terms as specified in equation (11) of section II. Despite the difference in specification, the $\gamma$ estimates are quite similar to those obtained from a production function, though smaller in absolute value. Begin with the preferred specification (in the middle row), which includes country and industry effects. The estimated coefficient on production workers is large and negative at $-1.83 \%$ (s.e. $=0.49 \%$ ), showing absolute labor saving technological change. The coefficients on nonproduction workers and capital are positive at $0.53 \%$ and $0.71 \%$ but not significantly different from zero, providing weak evidence of absolute skill-bias and absolute capital bias.

The sum of factor bias terms is $-0.59 \%(0.33)$, indicating weak evidence for a decline in returns to scale. If we assume unchanging returns, the implied estimate of $\gamma_{1}$ from the restricted regression is $-1.49 \%(0.43)$. That estimate is only slightly smaller in absolute value than the 
restricted estimate of $\gamma_{1}(-1.80 \%)$ in the production function specification. Like the production function estimates, these estimates imply substantially faster TFP growth for skill and capital intensive industries.

Omitting industry effects changes the estimated $\gamma_{1}$ coefficient to -0.98 . That change indicates TFP growth disproportionately concentrated in industries with high levels of production employment, conditional on country (as in the production function specification). Omitting country effects as well tends to lower the estimated $\gamma_{1}$ and $\gamma_{\mathrm{s}}$ coefficients in absolute value, while raising the coefficients on capital. I.e., countries with high levels of capital and low levels of employment tended to have faster measured TFP growth.

Recalling the discussion of potential biases above, the TFP specification is vulnerable to endogeneity bias. Country-industry specific productivity or price shocks could cause an endogenous adjustment of factor levels $(l, s$, and $k)$, which are measured by averaging the first and last measurements of the decade. In the production function estimates endogeneity bias was not a discernible problem, as shown by the similarity of instrumental variable and least squares estimates. So it's hard to see how they would be a major problem in this specification. If the major form of adjustment is through unskilled labor (which has the lowest adjustment costs), then endogeneity bias could explain why the TFP estimates have a less negative $\gamma_{1}$ estimate. Unfortunately, the instrument available in the production function specification, the lagged factor levels, $\mathrm{f}_{\mathrm{t}-1}$, are not valid here, - they are spuriously correlated with any measurement error in $\Delta \mathrm{f}$, which appear in the calculation of $\Delta$ TFP on the left-hand side of (11). (Those would tend to bias estimated coefficients upwards as they induce a positive spurious correlation with the error term. Thus, they do not help establish a lower bound for a bias that is probably upwards.) A conservative approach would be to borrow the estimated $m$ ( $8 \%$ ) from the production function specification and deflate the URS-restricted estimate of $\gamma_{1}$ from -1.49 to -1.37 .

Summarizing the three tables, both approaches show the same pattern: statistically significant evidence of absolute labor-saving technological change, weaker evidence of absolute skill-biased technological change and evidence of capital-biased technological change that is statistically insignificant in the TFP specification but significant in the production function specification. The restricted $\gamma_{1}$ estimate summarizes the results neatly (though the sum of factor 
bias terms rejects that restriction, the unrestricted estimates would make the following a slight understatement): conditional on industry and country effects, and allowing for fixed country and industry specific measurement error, a manufacturing industry in the 1980 s with double the $K / L$ ratio and double the $S / L$ ratio is predicted to have an annual TFP growth rate 1.4 to 1.8 percent higher. That is a remarkable level of labor saving technological change, compared with the sample average TFP growth rate of 1.6 percent 


\section{Middle Income Countries and The Technology Transfer Hypothesis}

Tables 4-6 all report extremely high rates of labor saving technological change. Are these estimates too large to be believed? In the Cobb-Douglas specification the $\gamma_{1}$ coefficient represents the shift in value-added share of production workers. Using that approach, the shifts reported in Table 1 suggest values of $\gamma_{1}$ between $-0.2 \%$ and $-0.5 \%$, which are only a fraction of the estimates in Tables 4-6 (-1.4\% to $-1.8 \%) \cdot{ }^{15}$ Estimated labor saving technological change is also high in another sense. If $\beta_{1}$ is about 0.3 and $\gamma_{1}$ is about -.015 , then in 20 years production workers will be quite useless in production!

A possible explanation for such strong evidence of factor-bias comes from the hypothesis of skill-biased technology transfer. Previous research suggested that during the 1980s middle income countries absorbed several vintages of technology from high income countries [Berman and Machin, 2000]. Perhaps this accelerated technological catchup induced factor bias in the 1980s for middle income countries at a rate much faster than that experienced at the technological frontier. (E.g., if technological convergence is 4 times as fast in middle income countries as the rate of advance at the frontier, then the labor-saving rate would be $4 \gamma_{1}$ in middle income countries.)

Accelerated factor-biased technology transfer in middle income countries implies that evidence of factor-bias be stronger in the middle income countries than in the high income countries in the1980s. Table 7 provides a test of that implication, reporting separate regression estimates for the nine high income countries and the ten middle income countries. Dividing the sample reduces precision. To make the interpretation easier I report only the URS-restricted results.

The high income countries provide a surprise. While the estimates without industry effects are similar to those reported for the sample as a whole, the preferred specification (with country

15 Part of the difference may be due to reallocation of production between industries. Table 7 below suggests that these reallocations favor production workers in middle income countries but work against them in high income countries. Yet reallocation between industries is too small to provide most of the answer. A more likely explanation is that the assumptions about supply and demand in labor market, which underly that calculation, are too restrictive. In particular, the Cobb-Douglas implies a unitary elasticity of factor demand. If manufacturing demand for unskilled labor is elastic, then a decline in demand for less skilled workers could result in a very small decline in their wagebill share. 
and industry effects) reports labor-biased technological change which is capital-saving! These coefficients are statistically insignificant, so they should not be interpreted as overturning the large body of evidence in the literature suggesting skill-bias in the U.S. and other high income countries. It is more likely that at the level of resolution this method has, we cannot find skill-bias in these countries.

More interesting is the contrast between the estimated factor-bias coefficients in middle and high income countries. Unlike the high income countries, the 10 middle income countries show strong evidence of capital-bias and of labor savings in technological change (in the preferred specification, including country and industry effects). The coefficient indicating skill-bias is positive but imprecisely estimated. The implied $\gamma_{1}$ estimate is $-2.71 \%(0.84)$, indicating very strong evidence of substantial labor-saving technological change in middle income countries. These results reinforce the view that middle income countries absorbed several vintages of factorbiased manufacturing technology in the $1980 \mathrm{~s}$, so that a $\gamma_{1}$ estimate of $-1.5 \%$ (or even $-2.5 \%$ ) overestimates the trend rate of labor-saving technological change at the frontier.

The contrast between estimates with and without industry effects in high and middle income countries sheds light on the sector-bias hypothesis of Haskell and Slaughter [1998]. Apparently, industry-specific measured productivity growth worked against production workers in the high income countries. ${ }^{16}$ In the middle income countries the contrast between the results with and without industry effects indicates that industry effects in measured productivity favored production workers. Overall the pattern in both subsamples of countries is consistent with the prediction of Heckscher-Ohlin trade theory in a period of declining trade restrictions: price changes favored capital and skill intensive industries in countries with high skill and high capital intensity, while price changes favored industries intensive in unskilled labor in countries with low

\footnotetext{
${ }^{16}$ These results suggest that the ambiguity expressed by Kahn and Lim [1998] about the interpretation of their estimates as evidence of skill augmenting technological change was well founded. They could not include industry effects in the same way as they had only one country to work with.
} 
skill and low capital intensity. ${ }^{17}$ Once these industry effects in productivity growth are accounted for, the full extent of labor saving technological change in middle income countries is evident.

\section{IMPLICATIONS}

The estimates assuming unchanging returns lend themselves to straightforward interpretation. The U.S. has about twice the measured K/L and S/L ratios as Cyprus and Portugal. The estimated rates of labor-saving bias, between $1.4 \%$ and $1.8 \%$ annually, imply TFP growth rates 1.4 to 1.8 percent higher in U.S. manufacturing than in the manufacturing sectors of those countries. Thus, all other things equal, manufacturing value added per worker will diverge quite quickly, with the labor productivity gap doubling every 39-50 years.

So why don't we observe divergence? Capital intensity in middle income countries is about half that of high income countries, and skill intensity is about 2/3 (though correcting for measurement error would lower that figure). For lower income countries the factor intensity gap is even larger.

One possible explanation for lack of TFP divergence is that suggested at the outset: replication is faster than invention, so that technological catch up compensates for factor bias. Another possibility is that URS does not hold in the 1980s, despite the replication argument offered: smaller industries had higher TFP growth rates, a force which favored convergence and partially compensated for the factor bias effect. This is the pattern suggested by the data when the sum of estimated $\gamma$ coefficients is negative. Note that those estimates cannot be interpreted as evidence for technological catch up across countries (or industries), as they are present in specifications that already include country effects.

The extent of compensation for factor bias (through these or some other mechanisms) can be roughly estimated by seeing how much of the cross-country variance in TFP growth rates is explained by country effects in a (URS restricted) regression which allows factor-bias. This calculation is not completely accurate: estimated country effects include not only the true country

\footnotetext{
${ }^{17}$ The pattern of these price effects is inconsistent with the argument that demand for skills increased in middle income countries because of foreign outsourcing to low income countries [Feenstra and Hanson 1996], as that would predict industry effects in the opposite direction.
} 
effect in TFP growth but also an estimation bias due to measurement error in factor levels (as shown in equation (10)). For instance, if a country miscodes less-skilled labor as skilled, and $\gamma_{\mathrm{s}}+$ $\gamma_{1}$ is negative, the estimated country effect will be biased downwards.

Figure 5 reports the result of that exercise in a plot of TFP growth rates against GDP/capita. Points labeled are the country effects in the industry and country effects specification for the pooled sample, reported in the rightmost column of Table $4 .{ }^{18}$ Squares represent TFP growth rates for these countries, as in the right panel of Figure 2. Estimated country effects exceed TFP growth in all but one middle income country (Columbia) and are lower than the TFP growth rate in all high income countries. Thus, the country effects show a negative correlation (illustrated by the regression line), indicating that once we account for factor-bias, there is evidence of TFP convergence. That negative correlation should not be overemphasized, as $\mathrm{t}=-0.9$ in that regression. On the other hand, if middle income countries did not tend to overstate measured skill intensity the slope would be even more negative. Similarly, if we used the middleincome factor-bias coefficients from Table 7, the slope would also be more negative. For these two reasons, TFP convergence conditional on factor-bias is stronger than indicated by the figure.

A final implication of labor saving technological change is this: If ratios of capital and skilled labor to unskilled labor are increasing (as would be efficient), TFP must accelerate under the simplifying assumption that $\beta^{\prime}{ }_{\mathrm{f}}=\gamma_{\mathrm{f}}$. This is apparent from equation (5), which implies that $\frac{d^{2} T F P}{d t^{2}}=\sum_{f} \gamma_{f} f^{\prime}(t)$ under the assumption. That implication is difficult to test because TFP fluctuates considerably over time. Nevertheless, two things are worth noting: First, in the very long run measured labor productivity has accelerated [Kremer 1993], and second, that this TFP acceleration is a fairly direct implication of the considerable evidence of skill-bias in the labor economics literature (cited above).

${ }^{18}$ A constant has been added to estimated country effects so that their mean is the same as that of the TFP growth rate. Otherwise they would reflect the conditional mean TFP growth rate with S/L and $\mathrm{K} / \mathrm{L}$ set equal to unity, which would be an unusual country indeed. 


\section{Conclusions}

Factor-biased technological change provides a plausible explanation for the lack of crosscountry convergence in total factor productivity. Factor bias is now a familiar finding for developed countries in the labor economics literature. In the countries sampled, most of the crossnational variation in growth rates of manufacturing value added per worker is TFP growth. Thus a factor-bias explanation for lack of convergence in TFP growth rates provides most of the explanation for lack of convergence in value added per worker in manufacturing. These, in turn, are highly correlated with (nonconvergent) growth rates in GDP/capita.

Most of the evidence on reasons for slow international convergence in income levels is due to cross-country variation and to studies of market failures within individual countries. ${ }^{19}$ Within-country variance from the manufacturing industries of a large number of countries provide a fresh, orthogonal, source of information. These data yield strong evidence that technological change is absolutely labor-saving, absolutely capital-biased and relatively skill-biased. Estimates are large, suggesting that a country or industry with twice the capital and skill intensity will have a total factor productivity growth rate $1.4 \%-1.8 \%$ higher annually. The data are unusually rich, allowing estimation of factor-bias coefficients which allow for country and industry effects in TFP growth. Estimated factor bias coefficients are driven for the most part by the ten middle income countries, suggesting that accelerated technology transfer to these countries in the 1980s caused unusually rapid, factor-biased technological change.

These results are based on manufacturing data from a single decade, so extrapolation to entire economies over longer periods should be done with caution. On the other hand, these data show considerable similarity to the Baumol-Barro-style 1960-90 nonconvergence diagram (the triangles and correlations of Section 2). So let's hazard the extrapolation anyway.

The good news inherent in these results is that a country accumulating skill and capital intensity has a twofold benefit: there is both an immediate increase in labor productivity and a repositioning which increases the benefit from future (absolute) skill and (absolute) capital bias in technological change. In this second sense current savings increase future growth.

\footnotetext{
${ }^{19}$ For a survey see Barro and Sala-I-Martin [1995], Ray [1998] or Weil [2000].
} 
Yet, Solow convergence through factor accumulation is quite slow in the 1960-90 period $^{20}$ (in these data or in Mankiw, Romer and Weil 1992, for example). Whatever economic mechanisms slowed factor accumulation in poorer countries over recent decades positioned them badly for factor-biased TFP growth.

Does factor-bias forever stifle convergence? Return to the two-factor illustration in Figure 3 and imagine a (closed economy) Solow or Ramsey growth model augmented with labor saving technological change. Designate B as the Ramsey steady state in which the marginal product of skill (human capital) is equal to the rate of time preference. Cross country convergence would be the motion from A to B, as skill-scarce (but otherwise identical) countries increase skill-intensity $(\mathrm{S} / \mathrm{L})$ and thus decrease the disparity in income per capita. The relative wages of skilled workers fall along this path till they reach their Ramsey steady state level.

Now consider the comparative statics of a (surprise) skill-biased technological change which shifts the isoquant for all countries from $\mathrm{F}_{\mathrm{t}-1}$ to $\mathrm{F}_{\mathrm{t}}$. The new Ramsey steady state will be at a point like $\mathrm{D}$, where the marginal product of skill is again equal to the rate of time preference. The shift in isoquants implies faster TFP growth for countries with higher skill intensity and causes divergence in income per capita.

Thus the Ramsey model augmented with factor-biased technological change admits both periods of divergence and periods of convergence. This interpretation of the cross-country data is inherently hopeful about convergence. Despite factor-bias, eventually Solow's decreasing returns mechanism induces all countries to arrive at point $\mathrm{D}$, with equal income per capita.

That argument underscores the importance of establishing the relative importance of factor-bias, market failures in accumulation and failures in technology transfer in explaining slow convergence. An examination of the1990s, during which factor-biased technological change may have spread to low-income countries such as China and India, would be a first empirical step in that agenda.

${ }^{20}$ That is the prediction of a model with constant returns to skill and capital combined [Barro1991]. Interestingly, these data cannot reject that possibility, especially for the middle income countries for which the point estimates indicate slightly increasing combined returns for skill and capital. 


\section{REFERENCES}

Acemoglu, Daron, and Fabrizio Zilibotti, “Productivity Differences,” MIT mimeo, April 2000.

Autor, David, Lawrence F. Katz and Alan Krueger, "Computing Inequality: Have Computers Changed the Labor Market?" Quarterly Journal of Economics, 113(4) (1998) 1169-1214.

Bartelsman, Eric and Wayne Gray "National Bureau of Economic Research Manufacturing Productivity Database" National Bureau of Economic Research, mimeo, 1994.

Barro, Robert "Economic Growth in a Cross-Section of Countries," Quarterly Journal of Economics 106, 407-444.

Barro, Robert and Jong-Wha Lee, "International Measures of Schooling Years and Schooling Quality," ftp://www.nber.org/pub/barro.lee, 1997.

Barro, Robert and Xavier Sala-I-Martin, Economic Growth, New York, McGraw Hill, 1995.

Basu, Susanto and David N. Weil, "Appropriate Technology and Growth," Quarterly Journal of Economics, 113(4) (1998) 1025-1054.

Baumol, W.J. "Productivity Growth, Convergence and Welfare: What the Long-run Data Show," American Economic Review, 76, (1986) 1072-1085.

Berman, Eli, John Bound and Zvi Griliches, "Changes in the demand for skilled labor within U.S. manufacturing industries: Evidence from the Annual Survey of Manufacturing," Quarterly Journal of Economics, CIX (1994), 367-98.

Berman, Eli, John Bound and Stephen Machin, "Implications of Skill-Biased Technological Change: International Evidence," National Bureau of Economic Research Working Paper No. 6166, 1997.

, "Implications of Skill-Biased Technological Change: International Evidence," Quarterly Journal of Economics, 113(4) ( 1998) 1245-1280.

Berman, Eli and Stephen Machin, "Skill-Biased Technology Transfer: Evidence of Factor Biased Technological Change in Developing Countries," Boston University mimeo, 2000.

Bound, John and George Johnson, "Changes in the structure of Wages During the 1980s: An Evaluation of Alternative Explanations," American Economic Review, LXXXII (1992), 371-392.

Bresnahan, Timothy F., and Manuel Trajtenberg, "General Purpose Technologies: `Engines of Growth?”, Journal of Econometrics, LXV: 1091-1126, 1997.

Christensen, Laurits R., Dale W. Jorgenson and Lawrence J. Lau, "Transcendental Logarithmic Production Frontiers," Review of Economics and Statistics 55:1, (February 1973) 28-45.

Doms, Mark, Timothy Dunne and Kenneth R. Troske "Workers, Wages and Technology," Quarterly Journal of Economics, CXII (1997), 253-290.

Eaton, Jonathan and Samuel Kortum “Trade in Ideas: Patenting and Productivity in the OECD," Journal of International Economics XL (1996) 251-278.

Eaton, Jonathan and Samuel Kortum, "International Technology Diffusion: Theory and Measurement," Journal of International Economics, 1999.

Feliciano, Zadia, "Workers and Trade Liberalization: The Impact of Trade Reforms in Mexico on Wages and Employment," Queen's College, mimeo, May 1995. 
Feenstra, Robert C. and Gordon Hanson, "Globalization, Outsourcing, and Wage Inequality" American Economic Review Paper and Proceedings, LXXXVI (1996), 240-245.

Freeman, Richard and Lawrence Katz, "Rising wage inequality: The United States vs. other advanced countries," in Working Under Different Rules, Richard Freeman, ed. (New York, NY: Russell Sage Foundation, 1994).

Goldin, Claudia, and Lawrence F. Katz, "Technology, Skill and the Wage Structure: Insights from the Past," American Economic Review LXXXVI (1996), 252-257.

Goldin, Claudia, and Lawrence F. Katz, "The Origins of Technology-Skill Complementarity," Quarterly Journal of Economics, CXIII (1998), 693-732.

Gottschalk, Peter and Mary Joyce, "Cross-national Differences in the Rise of Earnings Inequality-Market and Institutional Factors" Review of Economics and Statistics (1999?.

Griliches, Zvi "Capital-Skill Complementarity," Review of Economics and Statistics, 51 (November 1969), 465-468.

Griliches, Zvi and Dale W. Jorgenson "The Explanation of Productivity Change," Review of Economic Studies, 34(3), (July 1967).

Griliches, Zvi and Jacques Mairesse, "Productivity Functions: The Search for Identification," National Bureau of Economic Research Working Paper 5067, March 1995.

Hanson, Gordon H. and Ann Harrison, "Trade, Technology and Wage Inequality", National Bureau of Economic Research Working Paper 5110, 1995.

Haskel, Jonathan E. and Matthew J. Slaughter "Does the Sector Bias of Skill-Biased Technological Change Explain Changing Wage Inequality?" National Bureau of Economic Research Working Paper 6565, May 1998.

Helpman, Elhanan "Introduction," in Helpman (ed.) General Purpose Technologies and Economic Growth (Cambridge, MA: MIT Press, 1998).

Helpman, Elhanan and Gene M. Grossman Innovation and Growth in the Global Economy (Cambridge, MA: MIT Press, 1991).

Kahn, James A., and Jong-Soo Lim "Skilled-Labor Augmenting Technical Progress in U.S. Manufacturing," Quarterly Journal of Economics, 113(4) (November 1998) 1281-1308.

Katz, Lawrence F., Gary W. Loveman and David G. Blanchflower, "A comparison of Changes in the Structure of Wages in Four OECD Countries," in Differences and Changes in Wage Structures, Katz and Freeman, eds. (Chicago, IL: University of Chicago Press, 1995).

Katz, Lawrence F. and Kevin M. Murphy, "Changes in Relative Wages, 1963-1987: Supply and Demand Factors," Quarterly Journal of Economics, CVII (1992), 35-78.

Klenow, Peter, "Ideas vs. Rival Human Capital: Industry Evidence on Growth Models," Journal of Monetary Economics, 42 (August 1998), 3-24.

Kremer, Michael, "Population Growth and Technological Change: One Million B.C. to 1990," Quarterly Journal of Economics 108(3) 681-716, (August 1993).

Lawrence, Robert and Matthew Slaughter, "International Trade and U.S. wages in the 1980s: Great sucking sound or small hiccup," Brookings Papers on Economic Activity, II (1993), 161-227. 
Machin, Stephen, and John Van Reenen, "Technology and changes in skill structure: Evidence from Seven OECD Countries," Quarterly Journal of Economics, 113(4) (1998) 1215-1244.

Mankiw, N. Gregory, David Romer and David N. Weil "A Contribution to the Empirics of Economic Growth," Quarterly Journal of Economics, 107(2) (May 1992), 407-437.

Murphy, Kevin M. and Finis Welch, "The Structure of Wages," Quarterly Journal of Economics, CVII (1992), 285-326.

Nelson, Richard and Edmund Phelps, "Investment in Humans, Technological Diffusion and Economic Growth," American Economic Review Papers and Proceedings 56, 1966, 69-75.

Psacharolpoulos, George (1994) "Returns to Investment in Education: A Global Update," World Development 22(9) 1325-1343.

Psacharolpoulos, George (1999) "The Opportunity Cost of Child Labor: A Review of the Benefits of Education," University of Athens mimeo.

Ray, Debraj, Development Economics, (Princeton University Press: Princeton NJ, 1998)

Robbins, Donald J., "Trade, Trade Liberalization and Inequality in Latin America and East AsiaSynthesis of Seven Country Studies." Harvard, mimeo, 1995.

Solow, Robert “A Contribution to the Theory of Economic Growth," Quarterly Journal of Economics 70, (1956) 65-94.

Solow, Robert "Technical Change and the Aggregate Production Function," Review of Economics and Statistics, 39(3) (August 1957) 312-320.

Schumacher E.F., Small is Beautiful: Economics as if People Mattered (Harper and Row, New York, 1973).

Summers and Heston, "Penn World Table (Mark 5): An Expanded Set of International Comparisons, 1950-1988," Quarterly Journal of Economics , 106 (1991), 327-368.

United Nations, Dept. of Economic and Social Affairs, Statistical Office, Industrial Statistics Yearbook, Volume I: General Industrial Statistics, (New York, NY: 1992).

Weil, David N. Economic Growth, manuscript, Brown University, 2000.

Young, Alwyn "The Tyranny of Numbers: Confronting the Statistical Realities of the East Asian Growth Experience," Quarterly Journal of Economics 110, 641-680. 


\section{Table 1. Factor Shares in Value Added}

\begin{tabular}{l|cccccc} 
& \multicolumn{3}{|c}{ Middle Income } & \multicolumn{3}{c}{ High Income } \\
& $\sim 1980$ & $\sim 1990$ & change & $\sim 1980$ & $\sim 1990$ & change \\
\hline production & 25.5 & 23.1 & $\mathbf{- 2 . 4}$ & 30.3 & 25.7 & $\mathbf{- 4 . 6}$ \\
nonproduction & 10.1 & 10.2 & $\mathbf{+ 0 . 1}$ & 18.4 & 18.0 & $\mathbf{- 0 . 4}$ \\
capital & 64.4 & 66.7 & $\mathbf{+ 2 . 3}$ & 51.3 & 56.3 & $\mathbf{+ 5 . 0}$ \\
\hline
\end{tabular}

Notes: The wagebill shares of production and nonproduction workers are wagebill/value added. The capital share is the complement so that the three shares sum to one. These figures are calculated from the UN GIS database, using the same sample as regression results in the other Tables, which is restricted to countries for which capital can be calculated both near the beginning and near the end of the 1980s. Middle Income countries have GDP per capita between $\$ 2,000$ and \$10,000 US in 1980. They are: Turkey, Columbia, Czechoslovakia, Malta, Portugal, Chile, Cyprus, South Korea, Ireland and Spain. High Income countries (those with GDP per capital above \$10,000 US) are: Japan, UK, Austria, Finland, Denmark, West Germany, Sweden, Australia, US. 
Table 2. Sample Descriptive Statistics - 1980

\begin{tabular}{|c|c|c|c|c|c|c|c|c|}
\hline Country & $\begin{array}{c}\text { GDP/capita } \\
(1985 \$)\end{array}$ & $\begin{array}{c}\text { Manuf. } \\
\text { Value } \\
\text { Added / } \\
\text { Worker (\$) }\end{array}$ & $\begin{array}{l}\text { Manufactur } \\
\text { Value } \\
\text { Added as } \\
\% \text { of GDP }\end{array}$ & $\begin{array}{c}\text { Manufactu } \\
\text { Employme } \\
\mathrm{nt} \\
(1000 \mathrm{~s}) \\
\end{array}$ & $\begin{array}{c}\text { Annual } \\
\text { Production } \\
\text { Wage }(\$)\end{array}$ & $\begin{array}{c}\text { Annual } \\
\text { Non- } \\
\text { Production } \\
\text { Wage }(\$)\end{array}$ & $\begin{array}{l}\text { Proportion } \\
\text { Non- } \\
\text { production }\end{array}$ & $\begin{array}{c}\text { Years of } \\
\text { education } \\
\text { /adult }\end{array}$ \\
\hline \multicolumn{9}{|c|}{ A. Middle Income Group } \\
\hline Turkey & 2872 & 5780 & 14 & 795 & 3290 & 4312 & 0.22 & 2.6 \\
\hline Colombia & 2948 & 4662 & 23 & 508 & 2660 & 5139 & 0.27 & 4.2 \\
\hline S. Korea & 3093 & 6764 & 28 & 2015 & 3346 & 4772 & 0.21 & 6.8 \\
\hline $\begin{array}{l}\text { Czecho- } \\
\text { slovakia. }\end{array}$ & 3731 & 5651 & - & 2472 & 2780 & 3064 & 0.27 & \\
\hline Chile & 3898 & 7472 & 21 & 206 & 4711 & 14496 & 0.27 & 5.9 \\
\hline Malta & 4488 & 7790 & - & 25 & 5826 & 11584 & 0.15 & 6.3 \\
\hline Portugal & 4982 & 2390 & - & 663 & 4157 & 6766 & 0.14 & 3.2 \\
\hline Cyprus & 5289 & 6990 & - & 36 & 4884 & 7252 & 0.16 & 7.2 \\
\hline Ireland & 6828 & 11894 & - & 212 & 12929 & 18383 & 0.19 & 7.6 \\
\hline Spain & 7391 & 8835 & - & 1159 & 11842 & 16478 & 0.23 & 5.2 \\
\hline \multicolumn{9}{|c|}{ B. High Income Group } \\
\hline Japan & 10068 & 18467 & 29 & 10500 & 10506 & 11908 & 0.46 & 8.2 \\
\hline UK & 10161 & 13988 & 27 & 6462 & 14559 & 19045 & 0.30 & 8.3 \\
\hline Austria & 10499 & 15657 & 25 & 679 & 11602 & 19309 & 0.30 & 6.2 \\
\hline Finland & 10843 & 16256 & 28 & 531 & 13645 & 20597 & 0.24 & 9.6 \\
\hline Denmark & 11333 & 15664 & 20 & 381 & 22356 & 29948 & 0.28 & 10.1 \\
\hline W. Germany & 11916 & 20262 & - & 6302 & 20810 & 31450 & 0.28 & 8.5 \\
\hline Norway & 12141 & 14360 & 15 & 354 & 18619 & 25869 & 0.26 & 10.3 \\
\hline Sweden & 12447 & 17813 & 23 & 853 & 17520 & 27207 & 0.29 & 9.5 \\
\hline Australia & 12518 & 15702 & 19 & 1138 & 16380 & 19517 & 0.26 & 10.1 \\
\hline US & 15311 & 40078 & 22 & 19200 & 18357 & 28145 & 0.28 & 11.9 \\
\hline
\end{tabular}

Notes: All manufacturing figures are author's calculations from the United Nations General Industrial Statistics Database. These apply to 1980, except where otherwise noted. GDP/capita, is from the Penn World Tables. Percent of GDP in manufacturing is from World Development Indicators, 1999. Years of education/adult (aged 25 or more) are from the Barro-Lee data. All pecuniary figures reported in $1985 \$$ deflated by the implicit Laspeyres GDP deflator in the Penn World Tables.

${ }^{1}$ Employment reflects the sample rather than the population. Samples typically include only plants with ten or more employees. 
Table 3. Descriptive Statistics for Estimation

\begin{tabular}{|c|c|c|c|c|c|c|}
\hline Growth rate $(\mathrm{x} 10$ & \multicolumn{2}{|c|}{$\begin{array}{l}\text { All } 19 \\
\text { countries }\end{array}$} & \multicolumn{2}{|c|}{$\begin{array}{l}10 \text { middle income } \\
\text { countries }\end{array}$} & \multicolumn{2}{|c|}{$\begin{array}{l}9 \text { high income } \\
\text { countries }\end{array}$} \\
\hline $\begin{array}{l}\text { total factor } \\
\text { productivity }\end{array}$ & 1.62 & $(3.47)$ & 1.72 & $(4.59)$ & 1.52 & $(1.82)$ \\
\hline value added & 3.11 & $(5.30)$ & 4.16 & (6.90) & 2.10 & $(2.71)$ \\
\hline production & -0.73 & (3.16) & -0.02 & $(3.65)$ & -1.42 & $(2.42)$ \\
\hline nonproduction & 0.62 & $(3.36)$ & 1.44 & $(3.91)$ & -0.18 & $(2.49)$ \\
\hline capital & 2.64 & $(3.47)$ & 3.70 & $(4.24)$ & 1.62 & $(2.07)$ \\
\hline \multicolumn{7}{|l|}{ Log level of: } \\
\hline production & 10.44 & $(1.83)$ & 9.64 & $(1.73)$ & 11.20 & (1.59) \\
\hline nonproduction & 9.46 & $(2.05)$ & 8.44 & $(1.82)$ & 10.45 & $(1.76)$ \\
\hline capital & 21.53 & (2.09) & 20.40 & $(1.90)$ & 22.62 & (1.63) \\
\hline Observations & \multicolumn{2}{|c|}{422} & \multicolumn{2}{|c|}{197} & \multicolumn{2}{|c|}{225} \\
\hline
\end{tabular}

Notes: Each observation is a country-industry. Of the 532 potential observations (28 industries x 19 countries) 422 are available (79\%). Appendix 1 provides details of coverage by industry. Standard deviations in parentheses. Observations are weighted by their value-added share within each country. Total factor productivity is calculated using wagebill shares in value added as weights. Those weights are predicted by regression using a full set of country and industry indicators. Production worker weights are predicted with an $\mathrm{R}^{2}$ of 0.84 and nonproduction worker weights are predicted with an $\mathrm{R}^{2}$ of 0.77 . Capital weights are calculated as the complement so that the weights sum to one. 


\section{Table 4: Factor Bias Estimates from a Production Function}

Dependent variable: Annualized change in log value added (x100)

\begin{tabular}{|c|c|c|c|c|}
\hline & & country effects & $\begin{array}{c}. . \& \text { industry } \\
\text { effects }\end{array}$ & $\begin{array}{c}\text {.. \& impose } \\
\text { unchanging } \\
\text { returns }\end{array}$ \\
\hline \multirow[t]{2}{*}{ production } & -1.46 & -1.24 & -2.15 & \\
\hline & $(0.72)$ & $(0.44)$ & $(0.51)$ & \\
\hline \multirow[t]{2}{*}{ nonproduction } & -0.17 & 0.77 & 0.69 & 0.89 \\
\hline & $(0.69)$ & $(0.29)$ & $(0.43)$ & $(0.44)$ \\
\hline \multirow[t]{2}{*}{ capital } & 1.51 & 0.58 & 0.87 & 0.91 \\
\hline & $(0.61)$ & $(0.45)$ & $(0.41)$ & $(0.42)$ \\
\hline \multirow[t]{2}{*}{$\Delta$ production } & 34.9 & 22.5 & 21.5 & 19.3 \\
\hline & (12.9) & $(14.5)$ & $(13.8)$ & $(14.2)$ \\
\hline \multirow[t]{2}{*}{$\Delta$ nonproduction } & 27.1 & 41.7 & 48.6 & 49.9 \\
\hline & $(9.9)$ & (9.4) & $(9.2)$ & $(9.5)$ \\
\hline \multirow[t]{2}{*}{$\Delta$ capital } & 77.4 & 44.8 & 37.9 & 37.3 \\
\hline & (8.3) & (8.5) & (6.6) & $(7.0)$ \\
\hline 19 country effects & & $\mathrm{x}$ & $\mathrm{x}$ & $\mathrm{x}$ \\
\hline 28 industry effects & & & $\mathrm{x}$ & $\mathrm{x}$ \\
\hline $\mathrm{R}^{2}$ & 0.65 & 0.84 & 0.87 & 0.87 \\
\hline $\begin{array}{l}\text { Sum of elasticities } \\
(\beta \text { 's })\end{array}$ & $\begin{array}{l}139 \\
(10)\end{array}$ & $\begin{array}{l}109 \\
(09)\end{array}$ & $\begin{array}{l}108 \\
(11)\end{array}$ & $\begin{array}{l}107 \\
(11)\end{array}$ \\
\hline $\begin{array}{l}\text { sum of factor bias } \\
\text { coefficients ( } \gamma^{\prime} \text { s) }\end{array}$ & $\begin{array}{l}-0.11 \\
(0.20)\end{array}$ & $\begin{array}{c}0.10 \\
(0.13)\end{array}$ & $\begin{array}{l}-0.59 \\
(0.24)\end{array}$ & $\begin{array}{l}0 \\
-\end{array}$ \\
\hline $\begin{array}{l}\gamma_{1} \text { assuming } \\
\text { unchanged r.t.s. }\end{array}$ & & & & $\begin{array}{l}\mathbf{- 1 . 8 0} \\
(0.51)\end{array}$ \\
\hline
\end{tabular}

Notes: All specifications include 422 observations of industries within countries. Standard errors (in parentheses) are heteroskedasticity-consistent, allowing a country specific grouped error term. Observations are weighted by value added share within each country. The sum of factor bias coefficients sums estimated coefficients of production workers, nonproduction workers and capital. The coefficient $\gamma_{1}$ assuming unchanged returns to scale is the estimated coefficient on production workers, using the same specification but restricting the three factor bias coefficients to sum to zero. The "constant returns" specification imposes constant returns to scale. The dependent variable in that case is $\Delta \log$ (value added)$\Delta \log$ (production). For descriptive statistics see Table 3. Estimating equation is (10) in text. 


\section{Table 5: Factor Bias Estimates from a Production Function - Specification Checks}

Dependent variable: Annualized change in log value added (x100)

\begin{tabular}{|c|c|c|c|c|c|c|}
\hline & $\begin{array}{l}\text { lag level } \\
\text { instru- } \\
\text { ments }\end{array}$ & $\begin{array}{l}. . \& \text { un- } \\
\text { changing } \\
\text { returns }\end{array}$ & $\begin{array}{c}\text { impose } \\
\text { constant } \\
\text { returns }\end{array}$ & $\begin{array}{l}. . \& \text { un- } \\
\text { changing } \\
\text { returns }\end{array}$ & $\begin{array}{c}\text { impose } \\
\beta_{\mathrm{s}}=0\end{array}$ & $\begin{array}{c}. . \& \text { un- } \\
\text { changing } \\
\text { returns }\end{array}$ \\
\hline \multirow[t]{2}{*}{ production } & -2.10 & & -2.07 & & -2.07 & \\
\hline & $(0.55)$ & & $(0.53)$ & & $(0.58)$ & \\
\hline \multirow[t]{2}{*}{ nonproduction } & 0.63 & 0.82 & 0.70 & 0.89 & 0.47 & 0.71 \\
\hline & $(0.42)$ & $(0.44)$ & $(0.42)$ & $(0.43)$ & $(0.52)$ & $(0.52)$ \\
\hline \multirow[t]{2}{*}{ capital } & 0.89 & 0.93 & 0.82 & 0.87 & 0.87 & 0.93 \\
\hline & $(0.42)$ & $(0.43)$ & $(0.38)$ & $(0.41)$ & $(0.43)$ & $(0.45)$ \\
\hline \multirow[t]{2}{*}{$\Delta$ production } & 21.5 & 19.4 & 17.1 & 15.8 & 58.2 & 56.7 \\
\hline & $(13.9)$ & $(14.2)$ & - & - & $(10.4)$ & $(10.9)$ \\
\hline \multirow[t]{2}{*}{$\Delta$ nonproduction } & 48.6 & 49.8 & 48.4 & 49.6 & 0 & 0 \\
\hline & $(9.2)$ & $(9.5)$ & $(9.1)$ & $(9.5)$ & - & - \\
\hline \multirow[t]{2}{*}{$\Delta$ capital } & 37.9 & 37.3 & 34.5 & 34.6 & 48.5 & 48.1 \\
\hline & (6.6) & $(7.0)$ & (5.4) & $(5.5)$ & (7.4) & (7.9) \\
\hline $\begin{array}{l}19 \text { country effects \& } \\
28 \text { industry effects }\end{array}$ & $\mathrm{x}$ & $\mathrm{x}$ & $\mathrm{x}$ & $\mathrm{x}$ & $\mathrm{x}$ & $\mathrm{x}$ \\
\hline $\mathrm{R}^{2}$ & 0.87 & 0.87 & 0.78 & 0.77 & 0.84 & 0.84 \\
\hline $\begin{array}{l}\text { Sum of elasticities } \\
\left(\beta^{\prime} s\right)\end{array}$ & $\begin{array}{l}108 \\
(11)\end{array}$ & $\begin{array}{l}107 \\
(11)\end{array}$ & - & - & $\begin{array}{l}107 \\
(12)\end{array}$ & $\begin{array}{l}105 \\
(12)\end{array}$ \\
\hline sum of factor bias & -0.57 & 0 & -0.55 & 0 & -0.72 & 0 \\
\hline coefficients $(\gamma$ 's) & $(0.24)$ & - & $(0.26)$ & - & $(0.30)$ & - \\
\hline $\begin{array}{l}\gamma_{1} \text { assuming } \\
\text { unchanged r.t.s. }\end{array}$ & $\begin{array}{l}\mathbf{- 1 . 7 6} \\
(0.57)\end{array}$ & $\begin{array}{l}\mathbf{- 1 . 7 6} \\
(0.57)\end{array}$ & $\begin{array}{l}\mathbf{- 1 . 7 6} \\
(0.52)\end{array}$ & $\begin{array}{l}\mathbf{- 1 . 7 6} \\
(0.52)\end{array}$ & $\begin{array}{l}\mathbf{- 1 . 6 4} \\
(0.55)\end{array}$ & $\begin{array}{l}\mathbf{- 1 . 6 4} \\
(0.54)\end{array}$ \\
\hline
\end{tabular}

Notes: All specifications include 422 observations of industries within countries. Standard errors (in parentheses) are heteroskedasticity-consistent, allowing a country specific grouped error term.

Observations are weighted by value added share within each country. The sum of factor bias coefficients sums estimated coefficients of production workers, nonproduction workers and capital. The coefficient $\gamma_{1}$ assuming unchanged returns to scale is the estimated coefficient on production workers, using the same specification but restricting the three factor bias coefficients to sum to zero. The "constant returns" specification imposes constant returns to scale. The dependent variable in that case is $\Delta \log$ (value added)$\Delta \log$ (production). For descriptive statistics see Table 3. Estimating equation is (10) in text. 


\section{Table 6. Factor Bias Estimates using a TFP specification}

Dependent variable: Annualized change in TFP (x100)

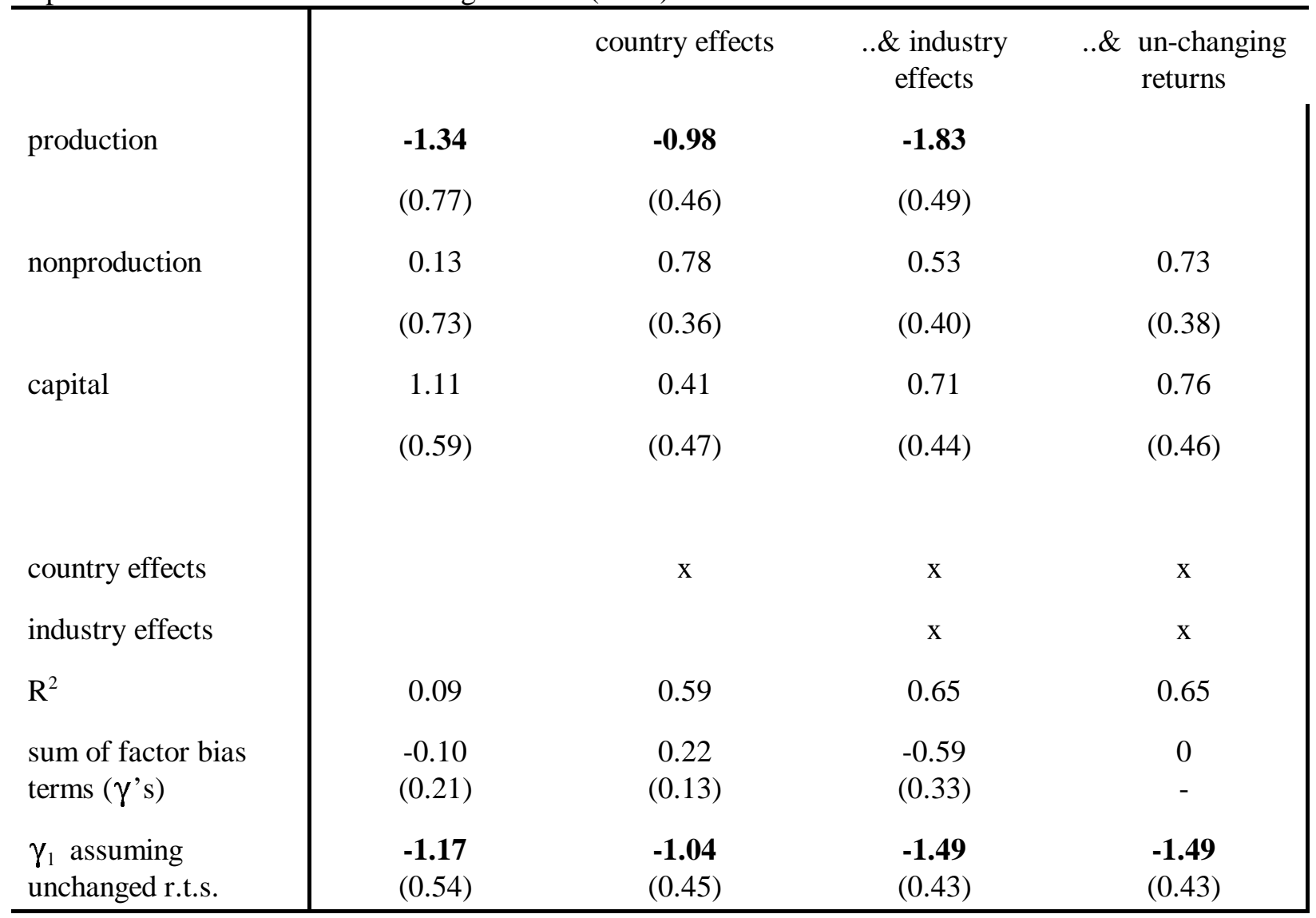

Notes: All specifications include 422 observations of industries within countries. Standard errors (reported in parentheses) are heteroskedasticity-consistent and allow a country specific grouped error term.

Observations are weighted by their value added share within each country. Total factor productivity is calculated using wagebill shares in value added as weights. In all but the rightmost column those weights are predicted using country and industry effects (see text and Table 3 for details). In the rightmost column the TFP weights are calculated by averaging across all industries and countries. The sum of factor bias coefficients sums estimated coefficients of production workers, nonproduction workers and capital. The coefficient $\gamma_{1}$ assuming unchanged returns to scale is the estimated coefficient on unskilled labor, calculated using the same specification but restricting the three factor bias coefficients to sum to zero. For descriptive statistics see Table 3. Estimating equation is (11) in text. 


\section{Table 7. Factor Bias Estimates: High vs. Middle Income Countries Unchanged Returns Assumed}

Dependent variable: Annualized change in log value added (x100)

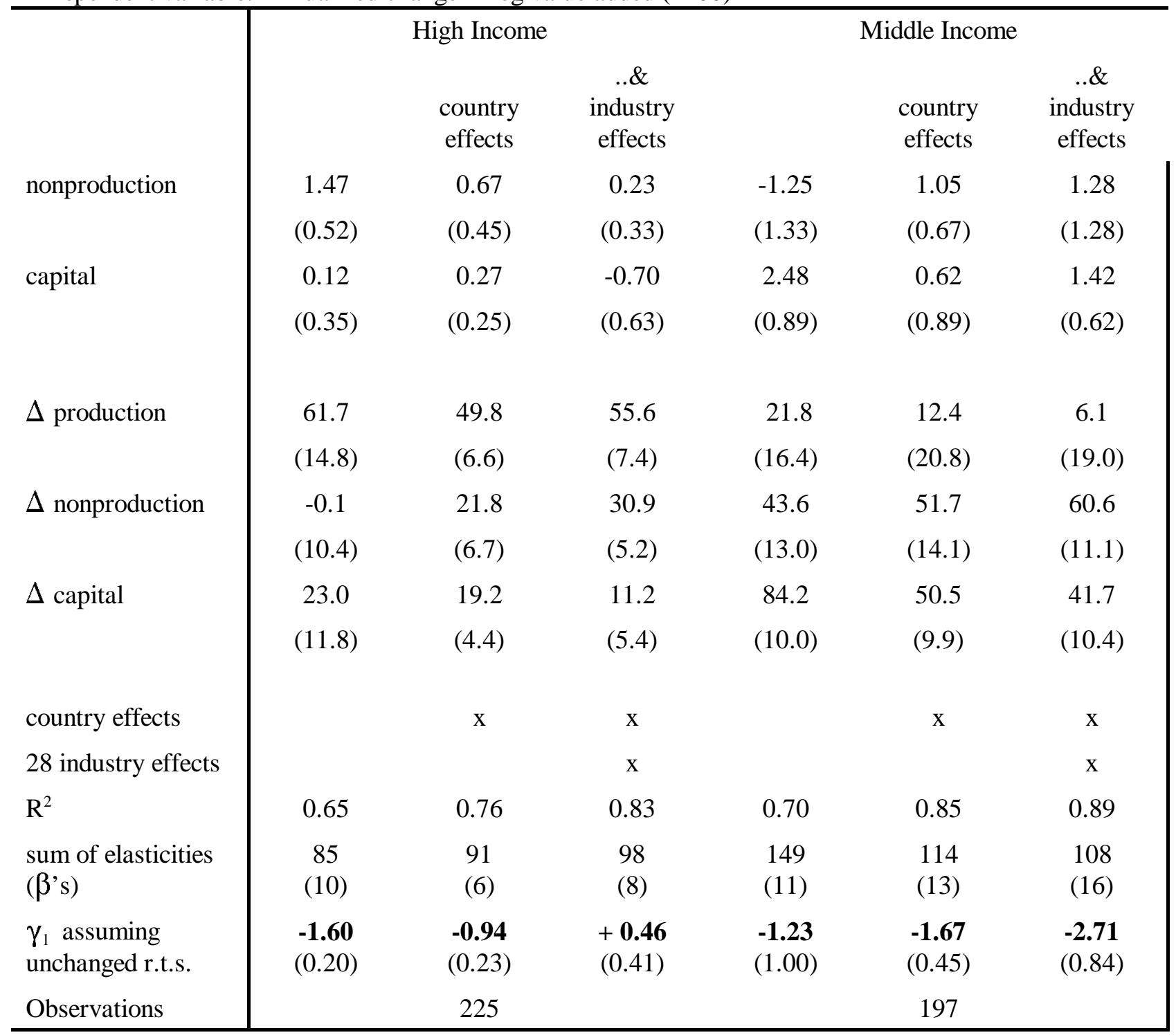

Notes: Standard errors (in parentheses) are heteroskedasticity-consistent, allowing a country specific grouped error term. Observations are weighted by value added share within each country. The sum of factor bias coefficients sums estimated coefficients of production workers, nonproduction workers and capital. The coefficient $\gamma_{1}$ assuming unchanged returns to scale is the estimated coefficient on production workers, using the same specification but restricting the three factor bias coefficients to sum to zero. The "constant returns" specification imposes constant returns to scale. The dependent variable in that case is $\Delta \log ($ value added)- $\Delta \log$ (production). For descriptive statistics see Table 3 . Estimating equation is (10) in text. 


\section{Table A1. Industry Coverage}

\begin{tabular}{|c|c|c|c|c|}
\hline \multirow[b]{2}{*}{ Industry } & \multicolumn{3}{|c|}{ Observations } & \multirow{2}{*}{$\begin{array}{c}\text { Value Added } \\
\text { Share } \\
(\%)\end{array}$} \\
\hline & $\begin{array}{l}10 \text { Middle } \\
\text { Income } \\
\text { Contries }\end{array}$ & $\begin{array}{c}9 \text { High } \\
\text { Income } \\
\text { Countries }\end{array}$ & Total & \\
\hline Food & 8 & 9 & 17 & 11.8 \\
\hline Beverages & 8 & 8 & 16 & 4.3 \\
\hline Tobacco & 7 & 7 & 14 & 1.9 \\
\hline Textiles & 10 & 9 & 19 & 5.7 \\
\hline Apparel & 9 & 9 & 18 & 4.0 \\
\hline Leather Products & 10 & 8 & 18 & 0.5 \\
\hline Footwear & 9 & 8 & 17 & 1.1 \\
\hline Food Products & 9 & 8 & 17 & 2.5 \\
\hline Furniture & 8 & 8 & 16 & 1.7 \\
\hline Paper Products & 10 & 9 & 19 & 4.7 \\
\hline Printing \& Publishing & 10 & 9 & 19 & 5.5 \\
\hline Industrial Chemicals & 6 & 8 & 14 & 3.6 \\
\hline Other Chemicals & 7 & 7 & 14 & 4.4 \\
\hline Petroleum Refineries & 6 & 6 & 12 & 1.5 \\
\hline Petroleum and Coal & 3 & 5 & 8 & 0.2 \\
\hline Rubber Products & 8 & 8 & 16 & 1.2 \\
\hline Plastic Products & 5 & 9 & 14 & 2.3 \\
\hline Pottery \& China & 4 & 7 & 11 & 0.3 \\
\hline Glass Products & 6 & 8 & 14 & 1.0 \\
\hline Non metalic minerals n.e.c. & 7 & 8 & 15 & 3.2 \\
\hline Iron and Steel & 4 & 8 & 12 & 2.5 \\
\hline Nonferrous metals & 5 & 7 & 12 & 2.2 \\
\hline Metal Products & 6 & 9 & 15 & 5.6 \\
\hline Machinery & 8 & 9 & 17 & 9.8 \\
\hline Electrical Machinery & 8 & 9 & 17 & 9.2 \\
\hline Transportation Equipment & 8 & 8 & 16 & 6.4 \\
\hline Professional Goods & 4 & 9 & 13 & 1.3 \\
\hline Other Goods & 4 & 8 & 12 & 0.8 \\
\hline Total & 197 & 225 & 422 & 100 \\
\hline
\end{tabular}

Notes: Observations record the number of countries reporting for each industry at both the beginning and end of the 1980s so that a useful observation existed. There are 282.5 digit ISIC industries and 19 countries so the potential number of industry-country observations is 532, of which 422 useful observations are available. The value added share reports the average share of manufacturing value added in that industry for countries reporting at the end of the 1980s. 


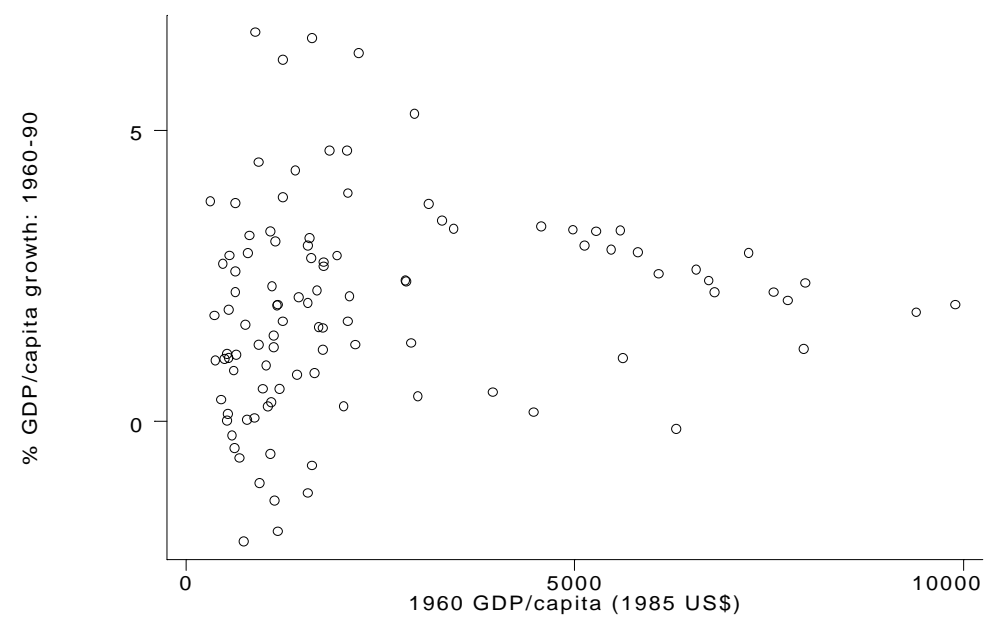

Figure 1A: Nonconvergence 1960-90

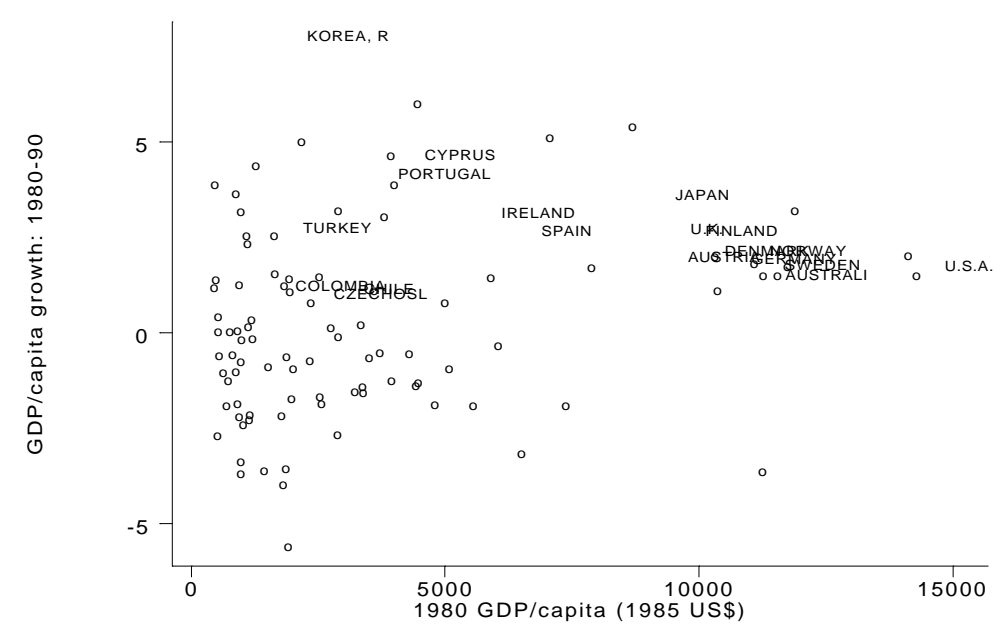

Figure 1B: Nonconvergence 1980-90

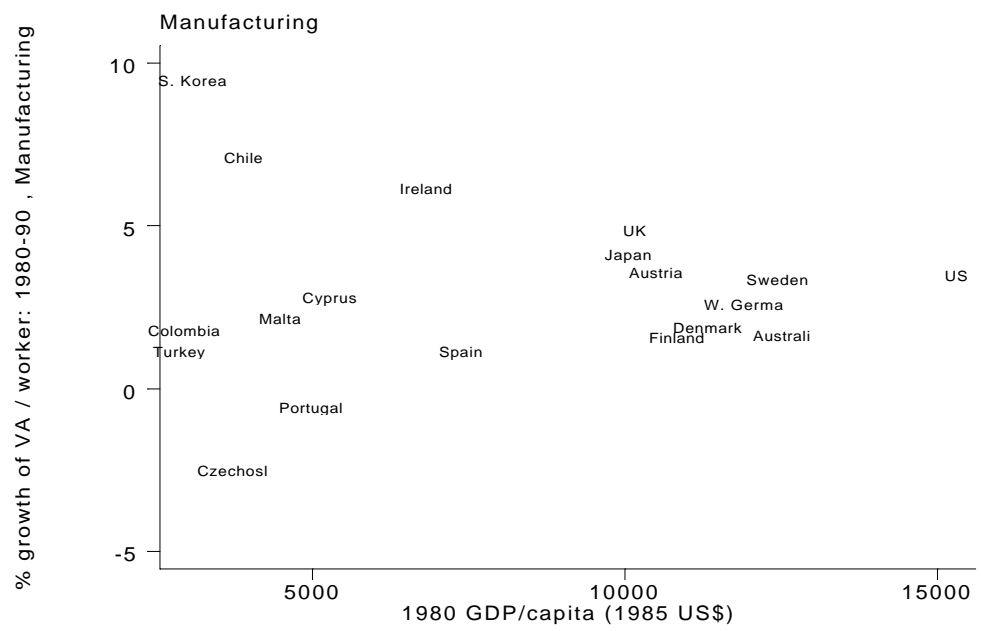

Figure 1C: Nonconvergence in Manufacturing Sample (product/worker) 

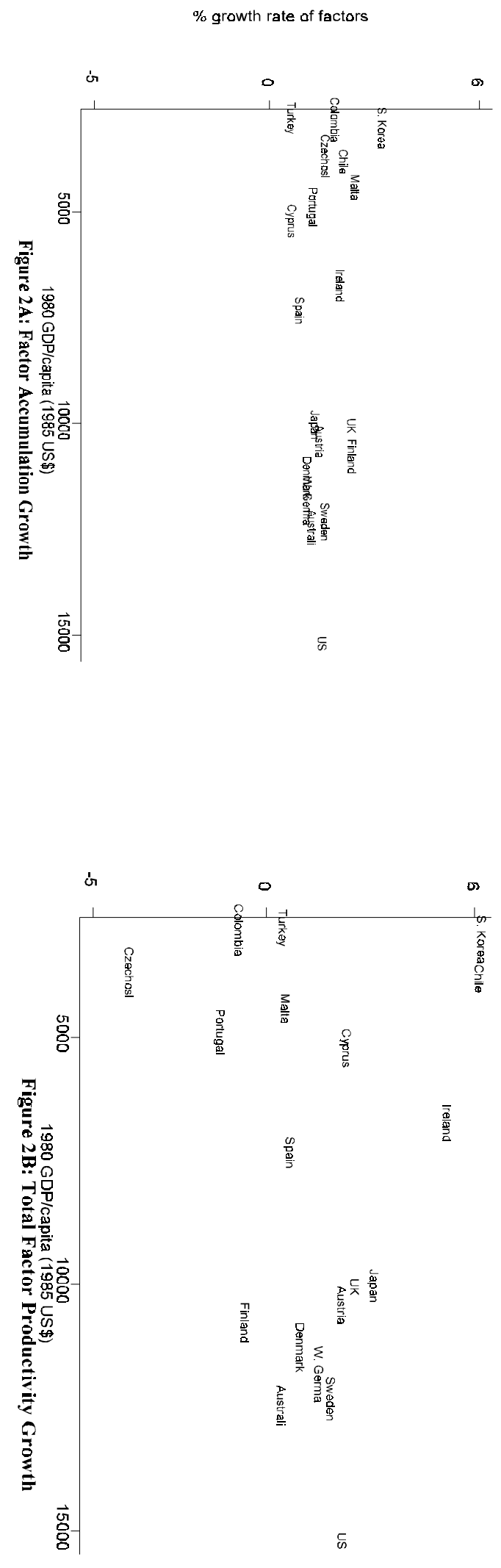


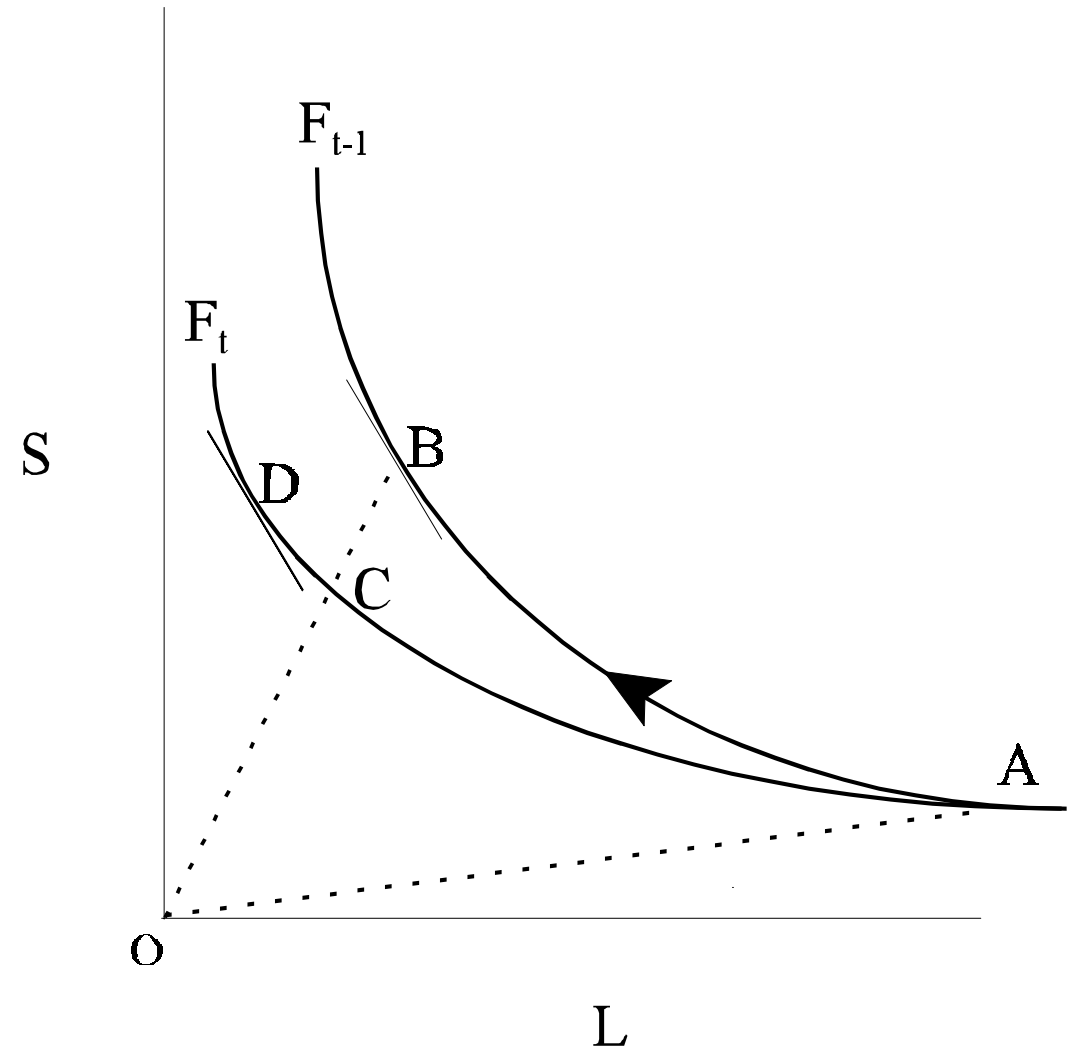

Figure 3: Technological Change with a Relative Skill Bias 

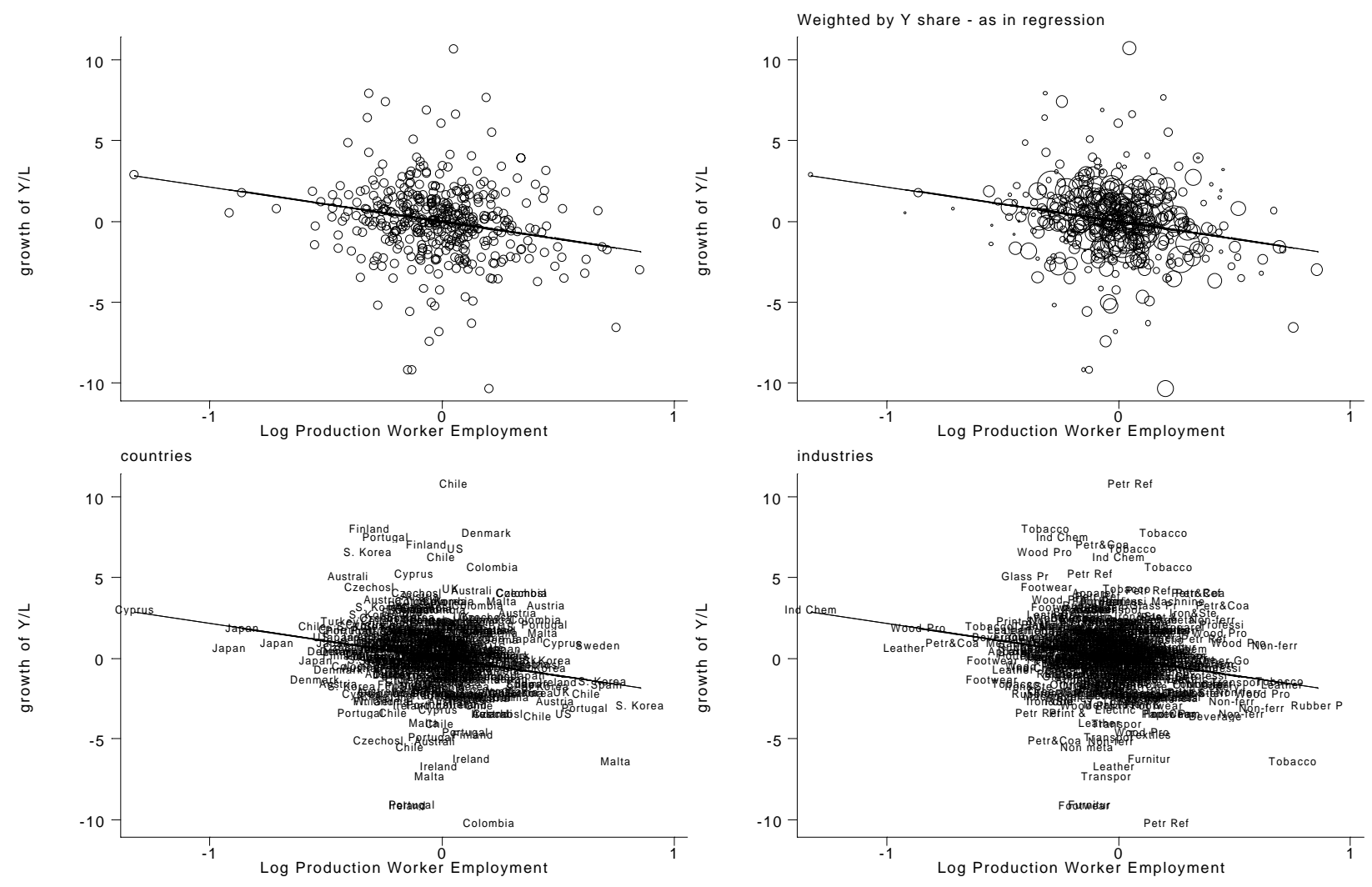

Figure 4: Leverage Plot of Labor-Saving Coefficient 


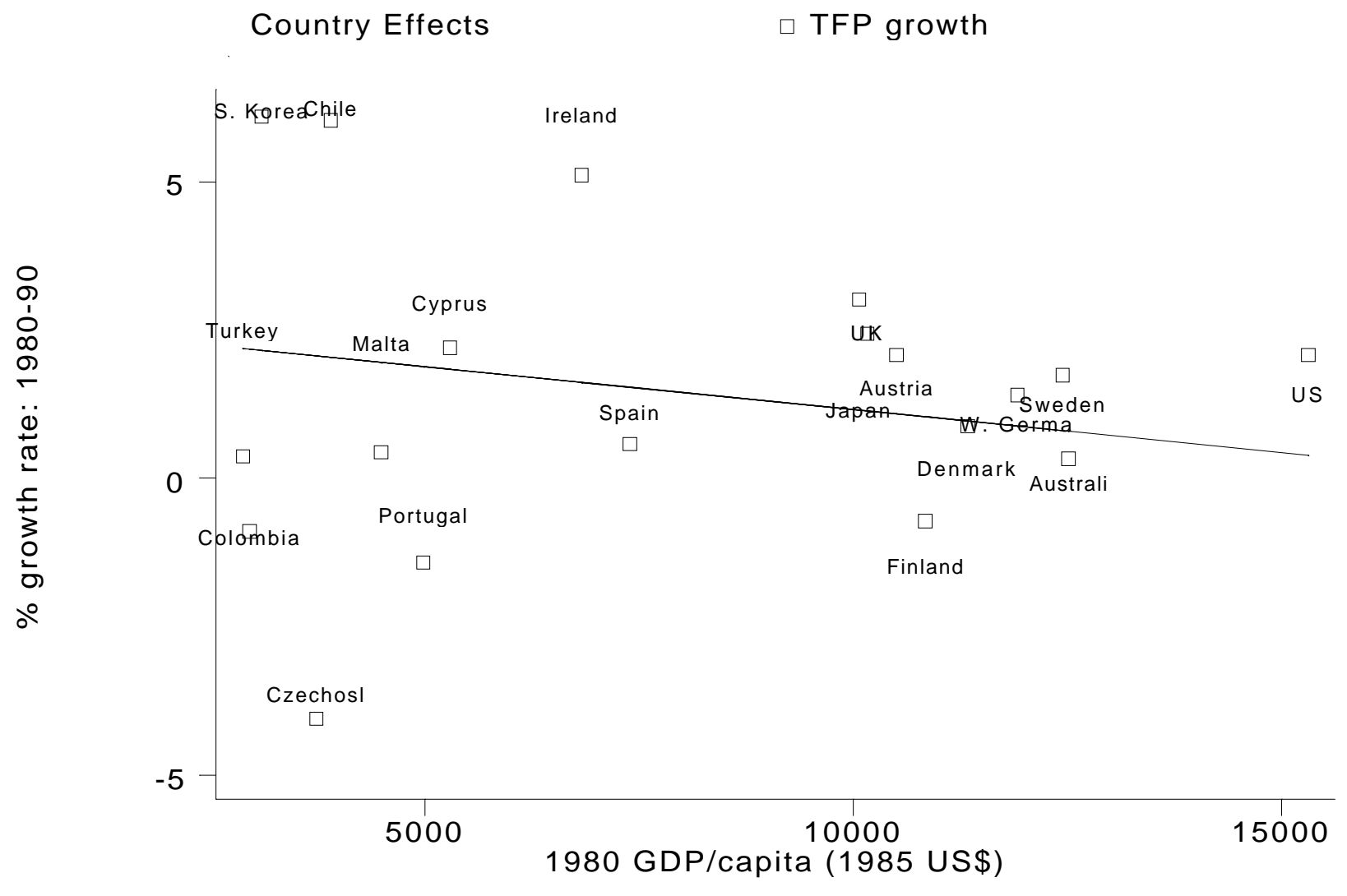

Figure 5: TFP Convergence Conditional on Factor Bias? 